\title{
Clinical Evidence of Antidepressant Effects of Insulin and Anti-Hyperglycemic Agents and Implications for the Pathophysiology of Depression-A Literature Review
}

\author{
Young Sup Woo, Hyun Kook Lim, Sheng-Min Wang and Won-Myong Bahk * (1) \\ Department of Psychiatry, College of Medicine, The Catholic University of Korea, Seoul 07345, Korea; \\ youngwoo@catholic.ac.kr (Y.S.W.); drblues@catholic.ac.kr (H.K.L.); smwang11@naver.com (S.-M.W.) \\ * Correspondence: wmbahk@catholic.ac.kr
}

Received: 2 July 2020; Accepted: 15 September 2020; Published: 22 September 2020

\begin{abstract}
Close connections between depression and type 2 diabetes (T2DM) have been suggested by many epidemiological and experimental studies. Disturbances in insulin sensitivity due to the disruption of various molecular pathways cause insulin resistance, which underpins many metabolic disorders, including diabetes, as well as depression. Several anti-hyperglycemic agents have demonstrated antidepressant properties in clinical trials, probably due to their action on brain targets based on the shared pathophysiology of depression and T2DM. In this article, we review reports of clinical trials examining the antidepressant effect of these medications, including insulin, metformin, glucagon like peptide-1 receptor agonists (GLP-1RA), and peroxisome proliferator-activated receptor (PPAR)- $\gamma$ agonists, and briefly consider possible molecular mechanisms underlying the associations between amelioration of insulin resistance and improvement of depressive symptoms. In doing so, we intend to suggest an integrative perspective for understanding the pathophysiology of depression.
\end{abstract}

Keywords: clinical trials; insulin resistance; depression; anti-hyperglycemic agents; pathophysiology

\section{Introduction}

Depression is a complex, heterogeneous illness associated with significant chronicity and considerable impairment of physical ability and psychosocial function [1]. Although antidepressants are the well-established first-line treatment for depression, current pharmacological therapies are often ineffective, yielding high rates of inadequate treatment response, reflected in recurrence or chronicity $[2,3]$. Furthermore, pharmacological therapy for depression is often associated with intolerance, with clinically substantive side effects including nausea, constipation/diarrhea, dry mouth, somnolence/insomnia, dizziness, sexual dysfunction, weight gain, increased appetite/anorexia, and with uncommon serious adverse effects including prolongation of corrected QT interval, increased risk of fracture, hyponatremia, and inhibition of platelet aggregation [4-6]. Therefore, there remains a need to elucidate novel targets that may yield improved efficacy, tolerability and, possibly, disease modifying effects.

The insulin signaling system has been proposed as a novel target in the treatment of depression [7-9]. Because a bi-directional association between diabetes/insulin resistance and depression has been described in many studies [9-13], an underlying shared pathophysiologic mechanism of depression and type 2 diabetes mellitus (T2DM) and anti-depressant effects of anti-diabetic agents have been explored in the field. Consequently, a growing body of evidence has suggested that altered insulin signaling, including insulin availability and/or sensitivity or availability of insulin receptors, is important to the underlying pathophysiology of depression [14,15]. 
Binding of the ligand to insulin receptors (IRs) generates intracellular signals via two main intracellular signaling pathways, the insulin receptor substrate (IRS)-phosphatidylinositol 3-kinase (PI3K)-Serine/threonine kinase (Akt) pathway and the mitogen-activated protein kinase (MAPK)/extracellular signal-regulated kinase (ERK) pathway, which are known to be involved in depression pathophysiology [16,17]. Moreover, insulin signaling may act to regulate mood by modulating neurogenesis. Hippocampal neurogenesis is known to be impaired in both depression and diabetes [18,19]. In addition, recent studies have demonstrated that altered insulin signaling in the brain induces monoaminergic dysfunction [20,21]. Recent pre-clinical and clinical trials have also demonstrated relationships between insulin signaling and depression; knockdown of insulin receptors in the hypothalamus or astrocytes generated depressive behavior in mice [22,23], and insulin administration may have improved mood and cognition in a few human studies as well $[14,24,25]$. Additionally, several preclinical studies on animal models suggested that high fat diet induced metabolic dysfunction could induce depressive-like behavior [26] via dysregulation of synaptic plasticity and insulin signaling [27], serotonin mediated neurotransmission [28,29], brain indoleamine 2,3-dioxygenase (IDO) activity [30], and intestinal microbiome and brain metabolome [31]. Other trials examining the antidepressant effect of repurposed anti-hyperglycemic (anti-diabetic) agents including the insulin sensitizing agent pioglitazone [32] and glucagon-like peptide-1 (GLP-1) receptor agonists [33,34] also suggest that the attenuation of insulin resistance could be a plausible target for the treatment of depression.

Therefore, the objective of this review was to delineate the antidepressant effects of insulin and anti-hyperglycemic agents in human subjects with depression. In addition, possible pathophysiological explanations for the suggested antidepressant effects of these agents were reviewed.

\section{Methods}

This study is a narrative review investigating the antidepressant effects of insulin and anti-hyperglycemic agents and their implications for the pathophysiology of depression. We searched electronic libraries including PubMed, EMBASE, and PsychINFO for studies published prior to February 2020 applying the filter function for clinical trials based on the following medical subject headings when possible or using text word terms: "Major depressive disorder (MDD)" or "Depression" or "Depressive disorder" or "Depressive symptoms" in combination with "anti-diabetic" or "anti-hyperglycemic" or "insulin" or "insulin receptor sensitizer" or "GLP-1" or "peroxisome proliferator-activated receptor gamma" or "PPAR $\gamma$ " or "metformin" or "liraglutide" or "exenatide" or "pioglitazone" or "thiazolidinedione" or "rosiglitazone". We included clinical studies with anti-hyperglycemic agents as monotherapy or as add-on treatment for human subjects as well as studies that evaluated depressive symptoms. Articles informed by observational studies and clinical trials, review, or meta-analysis articles relevant to the topic, and other publications cross-referenced for additional published articles were included. Studies were excluded if they included only subjects with diabetes or failed to use human subjects; unpublished data and conference abstracts were also excluded.

\section{Antidepressant Effects of Anti-Hyperglycemic Agents in Clinical Trials}

We found 21 clinical trials that met the inclusion criteria, including four studies of insulin, four of metformin, 11 of PPAR $\gamma$ receptor agonists, and two studies of GLP-1 receptor agonists (GLP-1RA). Table 1 summarizes the main characteristics of these clinical trials. 
Table 1. Characteristics of prior studies investigating antidepressant effects of anti-hyperglycemic agents.

\begin{tabular}{|c|c|c|c|c|c|c|c|c|c|c|c|c|}
\hline \multirow{2}{*}{$\begin{array}{l}\text { Author } \\
\text { (Year). }\end{array}$} & \multirow{2}{*}{$\begin{array}{c}\text { Study } \\
\text { Design }\end{array}$} & \multirow{2}{*}{ Subjects } & \multirow{2}{*}{$\begin{array}{c}\text { Psychiatric } \\
\text { Diagnosis }\end{array}$} & \multirow{2}{*}{$\begin{array}{l}\text { Number of } \\
\text { Subjects }\end{array}$} & \multicolumn{2}{|c|}{ Intervention } & \multicolumn{2}{|c|}{ Control } & \multirow{2}{*}{$\begin{array}{c}\text { Study } \\
\text { Duration }\end{array}$} & \multirow{2}{*}{$\begin{array}{l}\text { Depressive } \\
\text { Symptom } \\
\text { Measure }\end{array}$} & \multirow{2}{*}{ Results } & \multirow{2}{*}{$\begin{array}{c}\text { Correlations of Depression } \\
\text { with Glucose Intolerance } \\
\text { or Insulin Resistance }\end{array}$} \\
\hline & & & & & Drug & Dose & Drug & Dose & & & & \\
\hline $\begin{array}{l}\text { Reza et al. } \\
\text { [35] }\end{array}$ & $\begin{array}{c}\text { UB, } \\
\text { controlled }\end{array}$ & $\begin{array}{c}\text { T2DM, } \\
\text { older } \\
\text { subjects } \\
\text { ( } \geq 65 \text { years })\end{array}$ & Absence & 40 & $\begin{array}{c}\text { Insulin (SC) } \\
(n=30)\end{array}$ & & $\begin{array}{l}\text { Oral therapy } \\
\qquad(n=10)\end{array}$ & & $12 \mathrm{~W}$ & GDS-15 & $\begin{array}{l}\text { Significant change in } \\
\text { GDS-15 total score from } \\
\text { baseline to endpoint for } \\
\text { insulin group }\end{array}$ & N.R. \\
\hline Hendra [36] & UB RCT & $\begin{array}{l}\mathrm{T} 2 \mathrm{DM} \text { on } \\
\text { oral } \\
\text { therapy }\end{array}$ & Absence & 57 & $\begin{array}{c}\text { Insulin (SCs), } \\
\text { twice-daily } \\
\text { insulin } \\
(n=19) \\
\text { basal/bolus } \\
\text { insulin } \\
(n=19)\end{array}$ & $\begin{array}{l}\text { variable } \\
\text { dose }\end{array}$ & $\begin{array}{l}\text { Continue oral } \\
\text { therapy } \\
(n=19)\end{array}$ & & $26 \mathrm{~W}$ & HADS & $\begin{array}{l}\text { Changes in HADS score } \\
\text { was non-significant vs. } \\
\text { control group }\end{array}$ & N.R. \\
\hline Benedict [37] & DB-RCT & $\begin{array}{l}\text { Healthy } \\
\text { students }\end{array}$ & Absence & 38 & $\begin{array}{c}\text { Insulin (IN) } \\
(n=19)\end{array}$ & 160 IU/D & Placebo $(n=19)$ & & $8 \mathrm{~W}$ & EWL-N & $\begin{array}{l}\text { Significant difference } \\
\text { between insulin and } \\
\text { placebo in extroversion, } \\
\text { self-confidence, } \\
\text { well-being, depression } \\
\text { at endpoint }\end{array}$ & N.R. \\
\hline Cha [14] & $\begin{array}{l}\text { Crossover } \\
\text { DB-RCT }\end{array}$ & Non-diabetes & TR-MDD & 35 & Insulin (IN) & $160 \mathrm{IU} / \mathrm{D}$ & Placebo & & $12 \mathrm{~W}$ & MADRS & $\begin{array}{l}\text { No between-group } \\
\text { differences in change from } \\
\text { baseline on total MADRS } \\
\text { score or either of the } \\
\text { positive or negative } \\
\text { subscales of the PANAS }\end{array}$ & N.R. \\
\hline $\begin{array}{c}\text { Ackermann } \\
{[38]}\end{array}$ & DB-RCT & $\begin{array}{l}\text { impaired } \\
\text { glucose } \\
\text { tolerance }\end{array}$ & Absence & 3234 & $\begin{array}{l}\text { Metformin } \\
(n=1073)\end{array}$ & $1.7 \mathrm{~g} / \mathrm{D}$ & $\begin{array}{c}\text { Placebo } \\
(n=1082), \\
\text { intensive } \\
\text { lifestyle } \\
\text { intervention } \\
(n=1079)\end{array}$ & & $52 \mathrm{~W}$ & BDI & $\begin{array}{l}\text { Small but significant BDI } \\
\text { reduction from baseline to } \\
\text { endpoint for all } \\
\text { three groups }\end{array}$ & N.R. \\
\hline Guo [39] & DB-RCT & T2DM & Depression & 58 & $\begin{array}{l}\text { Metformin } \\
(n=29)\end{array}$ & $1-2 \mathrm{~g} / \mathrm{D}$ & Placebo $(n=29)$ & & $24 \mathrm{~W}$ & $\begin{array}{l}\text { MADRS, } \\
\text { HDRS-17 }\end{array}$ & $\begin{array}{l}\text { MADRS and HDRS-17 } \\
\text { scores significantly } \\
\text { decreased in } \\
\text { metformin group }\end{array}$ & $\begin{array}{l}\text { Depression scores were } \\
\text { positively correlated with } \\
\text { HbA1c levels }\end{array}$ \\
\hline Krysiak [40] & $\begin{array}{c}\text { UB, } \\
\text { controlled }\end{array}$ & $\begin{array}{l}\text { T2DM or } \\
\text { prediabetes }\end{array}$ & Absence & 87 & $\begin{array}{l}\text { Metformin } \\
(n=45)\end{array}$ & $1.7-3 \mathrm{~g} / \mathrm{D}$ & TAU $(n=42)$ & & $26 \mathrm{~W}$ & BDI-II & $\begin{array}{l}\text { Metformin reduced BDI-II } \\
\text { score significantly } \\
\text { compared to control }\end{array}$ & N.R. \\
\hline Jamilian [41] & DB-RCT & PCOS & Absence & 60 & $\begin{array}{l}\text { Metformin } \\
(n=30)\end{array}$ & $1.5 \mathrm{~g} / \mathrm{D}$ & $\begin{array}{l}\text { Myo-inositol } \\
\quad(n=30)\end{array}$ & $2 \mathrm{~g} / \mathrm{D}$ & $12 \mathrm{~W}$ & BDI & $\begin{array}{l}\text { Myo-inositol reduced BDI } \\
\text { score significantly } \\
\text { compared to metformin }\end{array}$ & N.R. \\
\hline Rasgon [42] & OL & $\begin{array}{l}\text { Non-diabetic } \\
\text { IR }\end{array}$ & $\begin{array}{l}\text { MDD or } \\
\text { BPD }\end{array}$ & 8 & $\begin{array}{l}\text { Rosiglitazone } \\
\qquad(n=8)\end{array}$ & $8 \mathrm{mg} / \mathrm{D}$ & N.A. & & $12 \mathrm{~W}$ & HDRS & $\begin{array}{l}\text { Significant declines in } \\
\text { HDRS score }\end{array}$ & $\begin{array}{l}\text { Changes in depressive } \\
\text { severity scores were not } \\
\text { correlated with changes in } \\
\text { endocrine variables }\end{array}$ \\
\hline
\end{tabular}


Table 1. Cont.

\begin{tabular}{|c|c|c|c|c|c|c|c|c|c|c|c|c|}
\hline \multirow{2}{*}{$\begin{array}{l}\text { Author } \\
\text { (Year). }\end{array}$} & \multirow{2}{*}{$\begin{array}{l}\text { Study } \\
\text { Design }\end{array}$} & \multirow{2}{*}{ Subjects } & \multirow{2}{*}{$\begin{array}{l}\text { Psychiatric } \\
\text { Diagnosis }\end{array}$} & \multirow{2}{*}{$\begin{array}{l}\text { Number of } \\
\text { Subjects }\end{array}$} & \multicolumn{2}{|c|}{ Intervention } & \multicolumn{2}{|c|}{ Control } & \multirow{2}{*}{$\begin{array}{c}\text { Study } \\
\text { Duration }\end{array}$} & \multirow{2}{*}{$\begin{array}{l}\text { Depressive } \\
\text { Symptom } \\
\text { Measure }\end{array}$} & \multirow{2}{*}{ Results } & \multirow{2}{*}{$\begin{array}{c}\text { Correlations of Depression } \\
\text { with Glucose Intolerance } \\
\text { or Insulin Resistance }\end{array}$} \\
\hline & & & & & Drug & Dose & Drug & Dose & & & & \\
\hline $\begin{array}{c}\text { Sepanjnia } \\
{[43]}\end{array}$ & DB-RCT & Non-diabetes & $\begin{array}{l}\text { Moderate } \\
\text { to severe } \\
\text { MDD }\end{array}$ & 40 & $\begin{array}{l}\text { Pioglitazone } \\
(n=20)\end{array}$ & 30 mg/D & Placebo $(n=20)$ & & $6 \mathrm{~W}$ & HDRS-17 & $\begin{array}{l}\text { Pioglitazone group had } \\
\text { significantly lower scores } \\
\text { at all time points than the } \\
\text { placebo group }\end{array}$ & N.R. \\
\hline Kemp [21] & $\mathrm{OL}$ & $\begin{array}{l}\text { Abdominal } \\
\text { obesity or } \\
\text { MetS }\end{array}$ & MDD & 23 & $\begin{array}{l}\text { Pioglitazone } \\
\quad(n=23)\end{array}$ & $\begin{array}{c}\text { Average } \\
32.7 \mathrm{mg} / \mathrm{D}\end{array}$ & N.A. & & $12 \mathrm{~W}$ & IDS, QIDS & $\begin{array}{l}\text { Pioglitazone significantly } \\
\text { reduced IDS and } \\
\text { QIDS scores }\end{array}$ & $\begin{array}{l}\text { The reduction in insulin } \\
\text { resistance was significantly } \\
\text { correlated with } \\
\text { improvement in } \\
\text { depression severity }\end{array}$ \\
\hline Kashani [44] & DB-RCT & PCOS & $\begin{array}{l}\text { Mild to } \\
\text { moderate } \\
\text { MDD } \\
\text { (HDRS } \\
<20)\end{array}$ & 40 & $\begin{array}{l}\text { Pioglitazone } \\
\quad(n=20)\end{array}$ & 30 mg/D & $\begin{array}{l}\text { Metformin } \\
(n=20)\end{array}$ & $1.5 \mathrm{~g} / \mathrm{D}$ & $6 \mathrm{~W}$ & HDRS-17 & $\begin{array}{l}\text { Pioglitazone was superior } \\
\text { to metformin in reducing } \\
\text { HDRS scores at the end of } \\
\text { the study }\end{array}$ & $\begin{array}{l}\text { No correlation between } \\
\text { changes in HOMA-IR } \\
\text { and HDRS }\end{array}$ \\
\hline Kemp [45] & OL & MetS or IR & BPD & 34 & $\begin{array}{l}\text { Pioglitazone } \\
\quad(n=34)\end{array}$ & $\begin{array}{c}\text { Average } \\
27.4 \mathrm{mg} / \mathrm{D}\end{array}$ & N.A & & $8 \mathrm{~W}$ & IDS, QIDS & $\begin{array}{l}\text { Pioglitazone significantly } \\
\text { reduced IDS and } \\
\text { QIDS scores }\end{array}$ & N.R. \\
\hline Roohafza [46] & DB-RCT & $\begin{array}{l}\text { Non-diabetic } \\
\text { MetS }\end{array}$ & Absence & 85 & $\begin{array}{c}\text { Pioglitazone } \\
\quad(n=40)\end{array}$ & 30 mg/D & placebo $(n=45)$ & & $24 \mathrm{~W}$ & HADS-D & $\begin{array}{l}\text { Pioglitazone was superior } \\
\text { in reducing } \\
\text { depression score }\end{array}$ & $\begin{array}{l}\text { Alterations in depression } \\
\text { severity were not correlated } \\
\text { with changes in insulin } \\
\text { resistance level (HOMA-IR) }\end{array}$ \\
\hline $\operatorname{Lin}[47]$ & DB-RCT & Non-diabetes & Depression & 37 & $\begin{array}{l}\text { Pioglitazone } \\
\quad(n=19)\end{array}$ & 30 mg/D & Placebo $(n=18)$ & & $12 \mathrm{~W}$ & HDRS-21 & $\begin{array}{l}\text { No significant difference } \\
\text { in mean decline in } \\
\text { HDRS-21 scores between } \\
\text { treatment groups }\end{array}$ & $\begin{array}{l}\text { Within the pioglitazone } \\
\text { group, change in HDRS-21 } \\
\text { was positively correlated to } \\
\text { change in OGTT. } \\
\text { Improvement in depression } \\
\text { was associated with } \\
\text { improvement in glucose } \\
\text { metabolism (OGTT) but } \\
\text { only in patients with } \\
\text { baseline insulin resistance }\end{array}$ \\
\hline $\mathrm{Hu}$ [48] & UB RCT & T2DM & $\begin{array}{l}\text { Post-stroke } \\
\text { depression }\end{array}$ & 118 & $\begin{array}{l}\text { Pioglitazone } \\
\quad(n=59)\end{array}$ & 30 mg/D & $\begin{array}{l}\text { Metformin } \\
(n=59)\end{array}$ & $1 \mathrm{~g} / \mathrm{D}$ & $3 \mathrm{M}$ & HDRS-21 & $\begin{array}{l}\text { HDRS-21 score in the } \\
\text { pioglitazone group was } \\
\text { lower than that in the } \\
\text { metformin group } \\
\text { at endpoint }\end{array}$ & N.R. \\
\hline $\begin{array}{c}\text { Zeinoddini } \\
\text { [49] }\end{array}$ & DB-RCT & Non-diabetes & BPD & 44 & $\begin{array}{l}\text { Pioglitazone } \\
\quad(n=22)\end{array}$ & 30 mg/D & Placebo $(n=22)$ & & $6 \mathrm{~W}$ & HDRS-17 & $\begin{array}{l}\text { Significantly greater } \\
\text { reduction in HDRS scores } \\
\text { in the pioglitazone group } \\
\text { than in the placebo group }\end{array}$ & N.R. \\
\hline Simuni [50] & DB-RCT & $\begin{array}{l}\text { Non-diabetes, } \\
\text { Parkinson's } \\
\text { disease }\end{array}$ & Absence & 210 & $\begin{array}{l}\text { Pioglitazone, } \\
15 \mathrm{mg} / \mathrm{D} \\
(n=72) \\
\text { Pioglitazone, } \\
45 \mathrm{mg} / \mathrm{D} \\
(n=67)\end{array}$ & $\begin{array}{c}15 \mathrm{mg} / \mathrm{D}, 45 \\
\mathrm{mg} / \mathrm{D}\end{array}$ & Placebo $(n=71)$ & & $44 \mathrm{~W}$ & GDS-15 & $\begin{array}{l}\text { The mean GDS change at } \\
44 \mathrm{w} \text { was similar to } \\
\text { treatment group }\end{array}$ & N.R. \\
\hline
\end{tabular}


Table 1. Cont.

\begin{tabular}{|c|c|c|c|c|c|c|c|c|c|c|c|c|}
\hline \multirow{2}{*}{$\begin{array}{l}\text { Author } \\
\text { (Year). }\end{array}$} & \multirow{2}{*}{$\begin{array}{c}\text { Study } \\
\text { Design }\end{array}$} & \multirow{2}{*}{ Subjects } & \multirow{2}{*}{$\begin{array}{l}\text { Psychiatric } \\
\text { Diagnosis }\end{array}$} & \multirow{2}{*}{$\begin{array}{c}\text { Number of } \\
\text { Subjects }\end{array}$} & \multicolumn{2}{|c|}{ Intervention } & \multicolumn{2}{|c|}{ Control } & \multirow{2}{*}{$\begin{array}{c}\text { Study } \\
\text { Duration }\end{array}$} & \multirow{2}{*}{$\begin{array}{l}\text { Depressive } \\
\text { Symptom } \\
\text { Measure }\end{array}$} & \multirow{2}{*}{ Results } & \multirow{2}{*}{$\begin{array}{l}\text { Correlations of Depression } \\
\text { with Glucose Intolerance } \\
\text { or Insulin Resistance }\end{array}$} \\
\hline & & & & & Drug & Dose & Drug & Dose & & & & \\
\hline Aftab [51] & DB-RCT & Non-diabetes & BPD & 37 & $\begin{array}{l}\text { Pioglitazone } \\
\quad(n=17)\end{array}$ & $15-45 \mathrm{mg} / \mathrm{D}$ & Placebo $(n=20)$ & & $8 \mathrm{~W}$ & $\begin{array}{c}\text { IDS, } \\
\text { MADRS }\end{array}$ & $\begin{array}{l}\text { Borderline significance of } \\
p \text {-value suggested a } \\
\text { strong trend in favor of } \\
\text { the placebo }(p=0.056) \text { in } \\
\text { reducing depressive } \\
\text { symptoms (IDS). No } \\
\text { significant difference } \\
\text { between treatment groups } \\
\text { in MADRS score change }\end{array}$ & $\begin{array}{l}\text { No statistically significant } \\
\text { correlation between insulin } \\
\text { resistance (HOMA-IR) and } \\
\text { change in depression score }\end{array}$ \\
\hline De Wit [52] & UB RCT & $\begin{array}{l}\text { T2DM on } \\
\text { insulin }\end{array}$ & Absence & 50 & $\begin{array}{l}\text { Liraglutide } \\
\quad(n=26)\end{array}$ & $1.8 \mathrm{mg} / \mathrm{D}$ & $\begin{array}{c}\text { Standard } \\
\text { therapy }(n=24)\end{array}$ & & $26 \mathrm{~W}$ & BDI-II & $\begin{array}{l}\text { No significant difference } \\
\text { in mean change in BDI-II } \\
\text { scores between } \\
\text { treatment groups }\end{array}$ & N.R. \\
\hline Mansur [33] & $\mathrm{OL}$ & Non-diabetes & $\mathrm{BP}$ or MDD & 19 & Liraglutide & $1.8 \mathrm{mg} / \mathrm{D}$ & & & $4 \mathrm{~W}$ & HDRS-17 & $\begin{array}{l}\text { Liraglutide significantly } \\
\text { reduced depressive } \\
\text { symptoms }\end{array}$ & N.R. \\
\hline
\end{tabular}

BDI: Beck Depression Inventory; BPD: bipolar depression; D: day; DB-RCT: double-blind randomized controlled trial; EWL-N: Eigenschaftswörterliste; GDS: Geriatric Depression Scale; HADS: Hospital Anxiety Depression Scale; HbA1c: Hemoglobin A1c; HDRS: Hamilton Depression Rating Scale; HOMA-IR: homeostatic model assessment for insulin resistance; IDS: Inventory of Depressive Symptomatology; IN: intranasal; IR: insulin resistance; M: months; MADRS: Montgomery Åsberg Depression Rating Scale; MDD: major depressive disorder; MetS: metabolic syndrome; N.A.: not applicable; N.R.: not reported; OGTT: oral glucose tolerance test; OL: open-label; PCOS: polycystic ovarian syndrome; QIDS: Quick Inventory of

Depressive Symptoms; SC: subcutaneous; T2DM: type 2 diabetes mellitus; TAU: treatment as usual; UB: unblended; W: weeks. 


\subsection{Insulin}

The antidepressant effects of subcutaneous insulin were investigated in two studies with T2DM patients. Reza et al. [35] reported significant improvements in depressive symptoms with subcutaneous insulin treatment in older (aged 65 years and over) type 2 diabetic patients. In this 12-week study, 30 consecutive patients advised to start insulin by the clinical diabetologist were treated with subcutaneous insulin, and 10 consecutive patients who remained on glucose-lowering drugs (combinations of gliclazide, metformin, and acarbose) were recruited as control subjects. Depressive symptoms at baseline, evaluated using the Geriatric Depression Scale (GDS) score, did not differ between the groups. Although the glycemic control remained relatively poor, with only a small reduction in Hemoglobin $\mathrm{A} 1 \mathrm{c}(\mathrm{HbA} 1 \mathrm{c})$ during the study in both groups, subcutaneous administration of insulin significantly reduced the GDS scores at both 4 weeks and 12 weeks compared to baseline; there was no change in the control group. However, in a follow-up study [36] of 57 older patients with poorly controlled T2DM, insulin was not associated with any change in depressive symptoms at the end of the 6-month study. The authors compared the effects of continuation of oral medication, change to isophane insulin, and basal/bolus insulin therapy. The results showed that the Hospital Anxiety and Depression Scale (HADS)-B (depression) scores were lower in the basal/bolus insulin group at 1 and 3 months compared to baseline, although the change at 6 months was not significant $(p=0.06)$. Moreover, insulin therapy did not improve depressive symptoms in a meta-analysis of diabetic patients [53]. Rather, diabetic patients on insulin therapy were significantly associated with the higher risk of depressive symptoms.

A few more clinical studies have investigated the effect of intranasal insulin on mood by studying subcutaneous insulin therapy in healthy or non-diabetic subjects. In an 8-week double-blind randomized comparison between intranasal insulin and placebo in 38 healthy subjects [37], intranasal insulin administration improved mood as well as memory. In that study, the authors assessed mood using an adjective check list designed to assess actual mood on 15 dimensions and assessed cognitive function with a word list, word-stem priming, and the Stroop test. After 8 weeks of intranasal insulin, delayed recall was significantly improved, feelings of well-being and self-confidence were increased, and anger ratings were decreased in comparison with placebo. Intranasally administered insulin could attenuate the hypothalamic-pituitary-adrenal (HPA) axis response to psychosocial stress, which has been associated with depression in numerous previous studies [54]. A single intranasal dose of insulin, 5 min before being exposed to the Trier Social Stress Test (TSST), diminished the HPA axis response to the TSST as measured by cortisol taken from saliva and plasma [55]. However, in a double-blind study examining the effect of intranasal insulin administration on cognitive function and mood symptoms in patients with treatment-resistant depression [14], intranasal insulin did not result in statistically significant improvement in overall mood or cognition. No significant difference was found between the effects of intranasal insulin and placebo on changes in total Montgomery Åsberg Depression Rating Scale (MADRS) scores, the Positive or Negative subscales of the Positive and Negative Affect Schedule (PANAS), or a global index of neurocognition.

\subsection{Metformin}

The effect of metformin on mood has been investigated in four studies which included subjects with T2DM and impaired glucose tolerance in polycystic ovarian syndrome (PCOS). In a 1-year diabetes prevention study of subjects with impaired glucose tolerance, Ackermann et al. [38] investigated the association between changes in body weight and changes in health status among three intervention groups (intensive lifestyle intervention, pharmacotherapy with metformin, and placebo) using scores on the Beck Depression Inventory (BDI) as a covariate. BDI total score was significantly, but only slightly, decreased during the 1-year treatment period in all three groups. At 1 year, the changes in BDI total scores were -1.02 in the intensive lifestyle intervention group $(p<0.001),-0.71$ in the metformin group $(p<0.001)$, and -0.58 in the placebo group $(p<0.001)$. However, it is not clear which intervention led to a greater decrease in BDI scores because the authors did not compare the treatment effects among the 
three groups. Moreover, as the baseline BDI scores were quite low (3.53 in the intensive lifestyle, 3.84 in the metformin, and 4.05 in the placebo group), the clinical significance of these results may be limited. However, in another randomized clinical trial (RCT), 24-week metformin treatment significantly improved MADRS and 17-item Hamilton Depression Rating Scale (HDRS) scores in patients with depression and T2DM [39]. The reduction in depressive symptoms was paralleled by improvement in $\mathrm{HbA} 1 \mathrm{c}$, but the correlation between $\mathrm{HbA} 1 \mathrm{c}$ changes and changes in depressive symptoms was not reported. In that study, chronic treatment with metformin also improved cognitive performance as assessed by the Wechsler Memory Scale-Revised. The authors suggested that administration of metformin may improve depressive symptoms comorbid with T2DM through improvements in cognitive performance. In addition, in a 6-month study of premenopausal women (aged 30-45 years) with T2DM or prediabetes, administration of metformin reduced, albeit insignificantly, the BDI-II score $(p=0.088)$ as well as the number of patients with depressive symptoms (BDI-II score 14 or higher, $p=0.056)$ in women with diabetes but not in those with prediabetes [40].

Metformin was included as an active control in three RCTs. In a study of women with PCOS, 12-week treatment with metformin $(-0.3 \pm 0.7)$ was marginally inferior to treatment with myo-inositol $(-1.0 \pm 1.7)$ in reducing depressive symptoms as measured by BDI scores [41]. The study's clinical value in terms of improving depression outcomes is limited because the subjects were not selected for depression, and the baseline BDI scores were relatively low (15.1 \pm 3.9 for the metformin group; $15.4 \pm 5.2$ for the myo-inositol group). Metformin was also inferior to pioglitazone at reducing depressive symptoms in patients with post-stroke depression and T2DM [48] and in patients with concomitant PCOS and MDD [44].

Recently, Moulton and colleagues conducted a meta-analysis of 19 published RCTs (five of metformin, two of peroxisome proliferator-activated receptor (PPAR)- $\gamma$ receptor agonists, two of incretin-based therapies, and one of insulin) on the effects of diabetes treatments on depressive symptoms. They found that metformin had similar effects to placebo on depressive symptoms (pooled effect size $=-0.49,95 \% \mathrm{CI}=-1.04$ to $0.074, p=0.089$ ) and was inferior to active controls (pooled effect size $=+1.32,95 \% \mathrm{CI}=0.31$ to $2.34, p<0.001)[56]$.

\subsection{PPAR $\gamma$ Receptor Agonists}

Numerous studies have examined the antidepressant effects of PPAR $\gamma$ receptor agonists. PPAR $\gamma$ agonists such as rosiglitazone and pioglitazone have been evaluated in four open-label clinical trials $[21,42,45,48]$ and six RCTs $[43,44,46,47,49,51]$. Majority of studies were conducted in subjects having metabolic or endocrinologic abnormalities such as T2DM, insulin resistance, obesity, metabolic syndrome (MetS) or PCOS [21,42,44-46,48], but some studies investigated antidepressant effects of insulin in subjects without metabolic abnormalities [43,47,49,51].

Rasgon and colleagues [42] tested the hypothesis that the addition of rosiglitazone, an insulinsensitizing agent, would improve mood in prediabetic patients with unipolar or bipolar depression. The authors additionally administered rosiglitazone with treatment as usual for 12 weeks to eight patients, and the results showed a decline in the mean HDRS score. The improvement in depressive symptoms was not associated with improvements in insulin sensitivity as measured by the Matsuda Index. In open-label studies of another PPAR $\gamma$ receptor agonist, pioglitazone, among subjects with both depressive symptoms and metabolic risk factors, pioglitazone improved depressive symptoms in subjects with MDD and abdominal obesity/MetS [21] and with post-stroke depression and T2DM [48]. Kemp et al. [21] reported that total scores on the Inventory of Depressive Symptomatology (IDS) decreased from $40.3 \pm 1.8$ at baseline to $19.2 \pm 1.8$ at week 12 in 23 MDD patients with abdominal obesity or metabolic syndrome patients who received pioglitazone. Moreover, Hu et al. [48] compared the antidepressant effects of pioglitazone versus metformin as adjunctive with fluoxetine in patients with post-stroke depression and T2DM; pioglitazone decreased HDRS scores significantly more than metformin within 3 months of treatment, independently of depression severity. 
Furthermore, in two double-blind randomized controlled trials with subjects with depression and comorbid conditions [44,46], pioglitazone showed significant antidepressant effects. Pioglitazone was superior to metformin in reducing HDRS scores at 6 weeks in patients with concomitant PCOS and MDD [44] and to placebo in reducing both depressive and anxiety symptoms, measured using the Hospital Anxiety and Depression Scale (HADS), in nondiabetic MetS patients [46]. Interestingly, the improvement in depressive symptoms was independent of the insulin-sensitizing effects of pioglitazone; in both studies, changes from baseline in homeostatic model assessment of insulin resistance (HOMA-IR) values were not correlated with the changes in depressive symptoms. Meanwhile, Simuni and colleagues [50] reported the results of a phase 2 double-blind RCT of pioglitazone in early Parkinson's disease, which showed no significant difference between pioglitazone and placebo in changes in GDS scores over 44 weeks.

Two RCTs have been performed in subjects with MDD but without metabolic abnormalities $[43,47]$. Pioglitazone adjunctive therapy for moderate to severe (17-item HDRS total score $\geq 22$ ) MDD patients was superior to placebo in reducing the HDRS total score during the course of the 6-week trial [43]. Moreover, the frequency of treatment response, remission (HDRS score $\leq$ seven), and early improvement ( $\geq 20 \%$ reduction in HDRS score within the first 2 weeks) was significantly higher in the pioglitazone group than in the placebo group. However, Lin et al. [47] reported no significant difference in the mean decline in HDRS scores between the adjunctive pioglitazone group and the placebo group when subjects both with and without insulin resistance were included. The difference in HDRS score change was only significant in subjects with insulin resistance. Another remarkable finding from this study was the age effect; pioglitazone was more effective in younger patients.

Studies of patients with bipolar depression have also been conducted [45,49,51]. In their proof-of-concept study, Kemp and colleagues [45] reported that adjunctive pioglitazone treatment significantly decreased the total IDS-C30 and Quick Inventory of Depressive Symptoms (QIDS) total scores at the end of an 8-week study in 34 patients with bipolar depression and MetS or insulin resistance. More than three-quarters of these patients, it should be noted, were experiencing treatment-resistant bipolar depression, having already failed two mood stabilizers or the combination of a mood stabilizer and a conventional antidepressant. Additionally, the improvement in depressive symptoms was associated with a reduction in the inflammatory biomarker interleukin (IL)-6. Zeinoddini et al. [49] also reported antidepressant effects of adjunctive pioglitazone relative to lithium in their double blind, placebo-controlled RCT. That study included 48 patients with bipolar I depression and without diabetes or MetS, who had previously failed to respond adequately in the current episode to a trial with lithium plus antidepressant. The total HDRS score was decreased significantly more in the pioglitazone group than in the placebo group over 6 weeks, and the difference was significant onwards from week 2 . However, another double-blind placebo-controlled RCT failed to show the antidepressant efficacy of pioglitazone in patients with bipolar depression [51]. Adjunctively administered pioglitazone with concomitant mood stabilizers, antipsychotics, and antidepressants with 38 bipolar depression patients showed significant differences in IDS-C30 and MADRS changes relative to the placebo control group during the 8-week study. However, there was a borderline significant difference between the two groups $(p=0.056)$ in the IDS-C30 score favoring the placebo. The authors noted that the discrepancies between these results and those of previous studies may have stemmed from characteristics of the subjects, including the higher heterogeneity, lower depression severity, and higher concomitant hypomanic/mixed symptomatology of their study population compared with Zeinoddini's study [49]. In addition, in the pioglitazone group, but not in the placebo group, leptin level was increased in subjects who showed a decrease in depression score, and this correlation was significant [51].

In any case, pioglitazone's antidepressant efficacy has been supported by meta-analyses $[32,56]$. In a meta-analysis of four double-blind RCTs [43,44,47,49], pioglitazone induced higher remission rates than control treatments $(27 \%$ versus $10 \%$, odds ratio $(\mathrm{OR})=3.3,95 \% \mathrm{CI}=1.4$ to $7.8, p=0.008)$. Subgroup analysis showed that the OR was even higher in MDD patients $(23 \%$ versus $8 \%$, OR $=5.9$, $95 \% \mathrm{CI}=1.6$ to $22.4, p=0.009)$ and in the patients without metabolic comorbidities ( $33 \%$ versus $10 \%$, 
$\mathrm{OR}=5.1,95 \% \mathrm{CI}=1.5$ to $17.9, p=0.01)$. The reduction in HDRS score was also significant in pioglitazone treatment compared with control treatments (mean difference $=3.3,95 \% \mathrm{CI}=2.6$ to $4.0, p<0.0001$ ). Another meta-analysis [56], which included four more RCTs $[46,48,50,51]$ than the meta-analysis by Colle et al. [32], also showed a significant treatment effect of pioglitazone (pooled effect size $=-0.68$, $95 \% \mathrm{CI}=-1.12$ to $-0.24, p=0.003$ ). Interestingly, being female was significantly associated with improvement in depression, but age, baseline severity of depressive symptoms, baseline HOMA-IR, and baseline fasting glucose were not associated with changes in depressive symptoms.

\subsection{GLP-1 Receptor Agonists (GLP-1RA)}

An open-label, short-term study with liraglutide reported significant reduction in depressive symptoms [33]. In this 4-week study, which included 19 subjects with MDD or bipolar disorder with impaired executive function, administration of liraglutide significantly reduced HDRS scores as a secondary outcome measure, as well as improving executive function. The change in HDRS score did not moderate the improvement in cognition. However, liraglutide failed to show a significant effect on depressive symptoms in an RCT [52]. Treatment with liraglutide for 26 weeks reduced body weight and $\mathrm{HbA} 1 \mathrm{c}$ significantly more than standard therapy, but it reduced BDI scores by only one point, which was not significant when compared with the control group.

\subsection{Safety and Tolerability}

The use of insulin could be limited by the risk of hypoglycemia, which is an important adverse effect of insulin therapy. Owing to the risk of hypoglycemia of intravenous insulin infusion, and the fact that high systemic doses would be needed to achieve functionally effective insulin concentrations in the CNS, this mode of administration is not viable for the psychiatric patients [57]. However, intranasal administration allows a non-invasive, direct delivery of insulin to the brain, by bypassing the blood-brain barrier (BBB) and thereby avoiding potential systemic side effects of lowering blood glucose levels [58,59]. In a clinical trial of intranasal insulin, it was well tolerated, and no subject exhibited hypoglycemia or other safety concerns [60].

There are also some adverse reports on the use of metformin. Abdominal pain and other gastrointestinal (GI) symptoms are not uncommon adverse effect of metformin. About $10 \%$ of patients stopped taking metformin due to its GI adverse effects [61]. Despite its rarity, lactic acidosis could result in a serious or lethal complication. Furthermore, metformin could be associated with CNS adverse effects. In an animal study, metformin therapy promoted neurodegenerative process by altering tau phosphorylation-dependent pathways in ApoE knockout mice [62]. Metformin also impaired cognitive function and increased the risk of Alzheimer's disease in patients with diabetes [63]. However, there was a contrary report suggesting that metformin use was not related to adverse outcomes of brain structures and cognitive function [64]. These discrepancies suggest that further studies are needed to determine whether metformin truly has a potential role in the prevention or treatment of neurodegenerative disorders [65].

Adverse effects of PPAR $\gamma$ receptor agonists on neuronal function were also noted in both animal and human studies [65]. Rosiglitazone was associated with neuronal apoptosis in the hippocampus of rats [66], and cognitive complications in patients with T2DM [67]. Although the use of PPAR $\gamma$ receptor agonists in T2DM is declining due to its adverse effects, a meta-analysis suggested a relatively favorable safety in MDD patients [32]. There were no deaths, major adverse events, and clinically significant weight gain or weight change [32]. However, caution needs to be exercised because some adverse effects such as increased appetite (15-25\%), headache (5-26\%), nausea (8.7-25\%), sexual dysfunction $(20 \%)$, abdominal pain (20\%), muscular pain (10-17.4\%), blurred vision (13-15\%), irritability (11.7\%), and edema $(11.7 \%)$ were common after pioglitazone administration [32].

GLP-1RA including liraglutide is commonly associated with GI adverse effects including nausea and vomiting [68]. However, they were all well-tolerated, and no severe adverse events or severe hypoglycemia were reported in an RCT [52]. Moreover, a pooled analysis of phase 2 and 3a trials of 
liraglutide for weight management showed liraglutide was generally safe with no clinically significant neuropsychiatric safety concerns [69].

\section{Factors Related to the Antidepressant Effects of Anti-Hyperglycemic Agents}

\subsection{Depression Severity and Class of Anti-Hyperglycemic Agents}

Among the aforementioned clinical trials, 11 studies included clinically depressed subjects $[14,21,33,39,42-45,47,49,51]$. Among the other studies, some results were positive, and others negative for antidepressant effects of insulin and anti-hyperglycemic agents among subjects who were not diagnosed with depression. Because the efficacy even of antidepressants is not fully supported for subthreshold or mild MDD [70,71], it is not surprising that some of these studies have had negative results. Moreover, the study by Cha et al. [14] was the only study of insulin treatment in MDD patients, but that study also included treatment-resistant subjects who would be likely not to respond well to treatment. In studies with clinically depressed subjects, metformin [39] and liraglutide [33] significantly reduced depressive symptom scores, and six of eight studies of PPAR $\gamma$ receptor agonists reported positive results $[21,42-45,49]$. Although a previous meta-analysis of diabetes treatments and their effects on depressive symptoms [56] suggested a significant treatment effect of pioglitazone, but not of metformin, on depressive symptoms, caution is required in interpreting the present results because the studies included here included both clinical (depression) and non-clinical (non-depressed) samples. Furthermore, subgroup analysis of MDD patients in another meta-analysis [32] supported the antidepressant effect of pioglitazone.

\subsection{Baseline Insulin Resistance}

Another point to be clarified is whether the antidepressant effect, if it exists, is demonstrated only in subjects with insulin resistance. Among 11 studies of clinical depression patients, six studies $[14,33,43,47,49]$ included subjects with uncomplicated depression, and five [21,39,42,44,45] included subjects with depression and comorbid T2DM or metabolic abnormalities. Interestingly, all five studies of subjects with comorbid depression and metabolic abnormalities reported positive depression-related outcomes of anti-hyperglycemic agents. Among the six studies of non-diabetic depression patients, antidepressant efficacy was not apparent in three studies [14,47,51]. However, it seems plausible that anti-hyperglycemic agents could have antidepressant effects regardless of the presence of insulin resistance; the effect of baseline insulin resistance on the change in depression severity was not confirmed in studies of subjects with comorbid depression and metabolic abnormalities, which suggests that the antidepressant effect of anti-hyperglycemic agents is not confined to patients with both conditions. Kemp et al. [21] reported that the presence or absence of metabolic syndrome did not appear to affect the change in depression severity. The reductions in depression scale scores were similar in patients with MetS to those in patients without. The effect of baseline HOMA-IR on depression improvement was non-significant in another study [44]. Moreover, a previous meta-analysis [56] reported that baseline HOMA-IR and baseline fasting glucose were not associated with changes in depressive symptoms during pioglitazone treatment. Additionally, a meta-analysis by Colle et al. [32] showed that, in a sub-analysis of patients without metabolic comorbidities, pioglitazone induced greater reductions in HDRS score than control treatment.

\subsection{Correlation between Changes in Depressive Symptoms and Insulin Resistance}

If the improvement in depression is not affected by the presence of baseline insulin resistance, another crucial question would be whether the improvement in depressive symptoms by anti-hyperglycemic agents could be attributable to the amelioration of insulin resistance. In studies of subjects with depression and comorbid T2DM or metabolic abnormalities, Kemp et al. [21] reported a correlation between improvement in depression severity and reduction in insulin resistance. Furthermore, Guo et al. [39] reported that HDRS-17 scores were positively correlated with HbA1c 
levels and suggested that these findings indicate an association between improvement in depressive symptoms and decreased $\mathrm{HbA} 1 \mathrm{c}$ levels by metformin treatment. In a study of subjects with glucose metabolism ranging across the insulin sensitivity spectrum, including insulin-sensitive, insulin-resistant, and/or prediabetic, but not diabetic, subjects [47], HDRS-21 score reduction was significantly associated with changes in oral glucose tolerance and fasting glucose among insulin-resistant patients, but not among insulin-sensitive patients. Additionally, Kashani et al. [44] reported no correlation between changes from baseline in HDRS scores and in HOMA-IR values, but also reported that greater changes in HOMA-IR values predicted greater reduction in HDRS scores, with a near-significant $p$-value $(p=0.088)$. However, no correlation between improvement in depressive symptoms and changes in metabolic parameters was observed in a study by Rasgon et al. [42], which included depressed patients with insulin resistance, and in another study by Aftab et al. [51], which included patients with bipolar depression and varying levels of metabolic abnormalities. To summarize, although most studies supported an association between changes in depressive symptom severity and insulin resistance and/or glucose homeostasis, whether anti-hyperglycemic agents have antidepressant effects through reduction in insulin resistance remains uncertain.

\section{Pathophysiologic Implications of Clinical Trials}

\subsection{Proposed Mechanism Underlying Links between Depression and Diabetes}

A body of evidence has addressed the correlation between depression and T2D. Although evidence from epidemiological studies strongly suggests reciprocal associations between the two conditions $[13,72,73]$, various confounding factors implicated in their comorbidity complicate the association [7]. However, several possible molecular links between depression and diabetes have been identified.

\subsubsection{Brain Insulin Resistance}

Brain insulin resistance is suggested as one of the most important mechanisms linking the pathophysiology of diabetes and depression. Insulin signaling pathways are triggered by the binding of ligands such as insulin-like growth factor (IGF) 1 and 2 and insulin to the transmembrane IR, and it induces several downstream signaling events involving different insulin-induced kinases such as PKC, AKT, mTOR, S6K1, SIK2, extracellular signal-regulated kinase 1/2 (ERK1/2), and ROCK1 [74,75]. The IR activities are distinct from metabolic IR functions in peripheral tissues, which highlight region specificity of IR properties. There are two IR isoforms, A and B, and the two IR isoforms have distinct structures and functions [76]. IR-A is a short isoform found solely in brain, and IR-B is a long isoform predominantly distributed in peripheral metabolic organs such as muscle, liver, kidney, and fat tissue. In brain, both IR-A and -B isoforms are abundantly expressed in olfactory bulb, hypothalamus, hippocampus, cerebral cortex, and cerebellum. However, on a cellular level, neurons express exclusively the IR-A, while astrocytes express both IR-A and IR-B [76]. IR-A also has 5-10 times higher binding affinity for IGF-2 than IR-B, and unlike IR-B, it binds IGF-2 even under physiologically relevant concentration and results in receptor activation [76]. Dysregulation of neuronal plasticity is known be associated with neuropathologic processes, and recent study studies suggest that IGF-2 might play as an essential regulator of neuronal plasticity [77-79]. Therefore, the IGF-2 sensitive, neuron-specific pattern of IR-A may underlie functions of IR that are characteristic for the brain [76].

Deficiencies in IR activation, insulin availability, and downstream IR-related mechanisms may result in aberrant IR-mediated functions and, subsequently, a broad range of brain disorders, including depression. In preclinical studies, depressive-like behaviors were triggered by insulin receptor knockout in the hypothalamus [22]. The association between impaired brain insulin signaling and depressive-like behavior could be mediated by mitochondrial dysfunction, increased reactive oxygen species, or leptin signaling, as suggested by studies with neuronal-specific knockout of insulin receptor (NIRKO) mice $[15,80]$. 
Furthermore, recent evidences suggested that cross-talk between insulin and glutamate signaling in excitotoxicity may play important roles in the brain insulin resistance [81]. Insulin modulates currents of the N-methyl-D-aspartate (NMDA) receptor in a dose-, time-, and NMDA subunit-specific manner through the IGF-1 receptor signaling pathway $[82,83]$ and increases the number of functional NMDA receptors in the cell membrane $[84,85]$. It has been reported that insulin increases the vulnerability of rat cortical neurons to the excitotoxic effects of glutamate, thereby contributing to cell death $[86,87]$. However, Nampoothiri et al. [88] reported conflicting results, in which they demonstrated that insulin blocks glutamate-induced neurotoxicity, thereby contributing to cell survival. The discrepancy among these results may be due to differences in experimental conditions. Moreover, as suggested by the result from Datusalia et al. [89] which showed that long-lasting hyper-insulinemia increases glutamate excitotoxicity in cortical neurons of insulin-resistant rats, the development of insulin resistance, caused by prolonged insulin exposure, may mask insulin effects [85]. Concurrently, a recent study showed that the short-term insulin exposure can improve neuroprotection against excitotoxicity and prevent glutamate mediated excitotoxicity whereas chronic insulin exposure results in neuronal insulin resistance and worsen excitotoxicity [85]. Although the exact molecular link between insulin resistance and glutamate excitotoxicity remains elusive, it has been suggested that the excitotoxic glutamate may induce the development of neuronal insulin resistance via inhibiting the IR/Akt/mTOR pathways [81]. As noted in previous studies, an abnormal increase in intracellular free $\mathrm{Ca}^{2+}$ concentration $\left(\left[\mathrm{Ca}^{2+}\right] \mathrm{i}\right)$ induces collapse of mitochondrial potential and result in the glutamate-induced excitotoxicity [90]. Pomytkin et al. [81] reported that activation of IR, Akt and mTOR, and inhibition of glycogen synthase kinase (GSK) $3 \beta$ were significantly decreased when significant mitochondrial depolarizations occurred due to glutamate-evoked massive influxes of $\mathrm{Ca}^{2+}$ into the cells.

It has been also suggested that elevated branched chain amino acids (BCAA) plasma levels may play a role in the link between depression and T2DM. In an animal model, chronic treatment with metformin normalized glucose metabolic impairments, suggesting that insulin resistance accompanied by elevated circulating levels of BCAAs in male mice fed a high-fat diet, which is in parallel with improvement in high fat diet-induced depressive-like effects [91]. Given that the elevated levels of circulating BCAA predict the severity of insulin resistance [92] while the rate of 5-hydroxytryptamine (5-HT) production may be limited because the uptake of tryptophan into the brain through BBB by the large neutral amino acid transporter 1 (LAT1) compete with BCAA [93], the rate of serotonin synthesis may be affected by BCAA [94]. In their study, Zemdegs et al. [91] suggested that metformin may produce antidepressant-like effect by decreasing circulating BCAA levels to favor serotonergic neurotransmission in the hippocampus.

Moreover, impaired insulin signaling may contribute to the pathogenesis of depression by regulating dopaminergic neurotransmission. Increased monoamine oxidase expression and dopamine turnover were observed in NIRKO mice [15], and decreased dopamine release was observed in astrocyte insulin receptor knockout mice [23]. Cai and colleagues [23] suggested that the association between the dopamine system and insulin signaling could be moderated by reductions in purinergic signaling on dopaminergic neurons. In addition, alterations in dopamine neurotransmission in the reward circuitry were also disrupted by a high-fat diet, inducing depressive-like behavior in mice through mediation of impaired brain insulin signaling [26]. The suggested mechanisms that mediate insulin signaling and dopaminergic neurotransmission, including mitochondrial dysfunction [95-97], oxidative stress [98-100], impaired leptin [101,102] and purinergic signaling [103], and disrupted dopaminergic neurotransmission [104], are known to play important roles in the pathophysiology of depression.

\subsubsection{Immune/Inflammatory, Oxidative, and Nitrosative Stress}

A body of the literature suggests that activated immune/inflammatory and oxidative stress (IO and NS) pathways and consequent mitochondrial dysfunction may play a role in the pathophysiology of major psychiatric disorders including MDD by causing dysfunction in synaptic or neuronal plasticity 
and neuronal signaling, as well as in neuronal survival and death [105-108]. IO and NS pathways are also thought to contribute to the pathways underpinning the development of metabolic disorders, including insulin resistance [109].

It is well known that some pro-inflammatory biomarkers, including interleukin (IL)-6, tumor necrosis factor (TNF)- $\alpha$, and C-reactive protein (CRP), are commonly increased in diabetes [110] and depression [111], and evidence indicates that depression and T2DM share biological mechanisms, namely, overactivation of the immune response, leading to a cytokine-mediated inflammatory response [112]. TNF- $\alpha$ is one of the most thoroughly studied pro-inflammatory biomarkers for both depression and T2DM. In preclinical studies, TNF- $\alpha$ administrated by an intracerebroventricular route produced depressive-like behavior, which was counteracted by anti TNF- $\alpha$ antibody and knockout of the TNF- $\alpha$ receptor 1 [113]. The depressogenic effect of TNF- $\alpha$ may be related to impaired serotonergic neurotransmission. TNF- $\alpha$ can reduce central nervous system (CNS) serotonin levels by increasing the degradation of tryptophan through induction of IDO, an enzyme that catabolizes the serotonin precursor tryptophan in a TNF- $\alpha$ dependent manner and activating the serotonin transporter (SERT) $[114,115]$. Furthermore, TNF- $\alpha$ can impair insulin signaling. TNF- $\alpha$ activates stress-response kinase pathways, including the IкB kinase $\beta(\mathrm{IKK} \beta)$ /nuclear factor $\kappa \mathrm{B}(\mathrm{NF} \kappa \mathrm{B})$ and c-Jun $N$-terminal kinase (JNK) pathways, which promote insulin resistance via phosphorylation of IRS1 on serine residues [116], and by decreasing expression of GLUT-4 glucose transporters, which are crucial to insulin transmembrane signaling $[75,117]$. In addition, TNF- $\alpha$ was shown to disrupt blood-brain barrier (BBB) integrity in a mouse model of depression [118] and in patients with T2DM [119], and to increase BBB permeability, which is restored by treatment with anti-inflammatory drugs [118]. Increased BBB permeability could allow for easier entry of both cytokines and immune cells into the brain [120], exacerbating the allostatic load to the HPA axis, leading to its dysregulation [7].

Disturbed antioxidant defenses in depression are indicated by reduced antioxidant molecules, including ubiquinone (coenzyme Q10), vitamins D and E, high-density lipoprotein cholesterol (HDL-c), glutathione peroxidase, and zinc [106,121,122]. The product of lipid peroxidation, malondialdehyde (MDA) $[123,124]$ and activities of antioxidative enzymes such as catalase (CAT) and superoxide dismutase (SOD), along with reduced glutathione (GSH), also indicate the role of oxidative stress in depression [124]. In addition, plasma activity of Paraoxonase 1 (PON1), a potent antioxidant that protects against lipid peroxidation, is lower in patients with depression [125]. The imbalance between oxidative stress and antioxidative defenses leads to dysregulation of brain functions and abnormalities in neuronal signaling, which have been shown to be correlated with the pathogenesis and progression of depression [126]. Phospholipids in the brain are susceptible to reactive oxygen species (ROS)-mediated peroxidation. Increased peroxidation of lipids in the brain is an important event in the pathogenesis of depression $[127,128]$. Depression is also accompanied by nitrosative and nitro-oxidative stress. Nitric oxide (NO), which is produced by NO synthase (NOS), plays a critical role as a neurotransmitter in the CNS, although high levels are associated with neuronal damage and apoptosis [129]. In depression, the activity of endothelial or neuronal NOS was reduced, but plasma levels of nitrate and nitrite levels were increased and normalized after recovery from depression [130]. Increased levels of serum NO accompany depressive symptoms such as psychomotor retardation, sexual dysfunction, weight loss, fatigue, irritability, cognitive dysfunction, and increased suicidal risk [130-132]. This NO dysregulation in depression may be the consequence of increased production of NO due to increased production of inducible NOS (iNOS), a main NOS isoform in the inflammatory cells, including glial cells capable of producing higher levels of NO [133,134].

Oxidative and nitrosative stress pathways also play a central role in metabolic disorders including insulin resistance [135]. Increased free radicals, together with reduced antioxidants in adipocytes, have been reported in numerous studies [75]. For example, the activity of PON1 is lowered, and the levels of MDA are increased in people with MetS [109]. The imbalance of oxidative stress and antioxidant defenses can potentially reduce insulin sensitivity and increase insulin resistance in peripheral tissues [109]. It is suggested that insulin resistance can be induced by oxidative stress, which impairs 
insulin signaling. Oxidative stress activates serine/threonine kinase cascades, such as IKK $\beta / N F K B$ and JNK, which, in turn, promote insulin resistance via phosphorylation of IRS proteins, accelerating the degradation of IRS [136] and decreasing expression of GLUT-4 glucose transporters that are crucial to insulin transmembrane signaling $[75,117]$. Interestingly, patients with insulin resistance have high MDA levels, and MDA concentration is associated with waist-to-hip ratio [137], suggesting a possible contributory role of obesity in the development of insulin resistance via IO and NS pathways. In obese subjects, tissue expression and circulating concentration of pro-inflammatory cytokines and adipokines have been observed [138]. Furthermore, PPAR $\gamma$, the master regulator of adipogenesis and adipocyte differentiation, is downregulated or dysregulated in obese patients [139]. Systemic oxidative stress upregulates stress-activated kinases (SAPK) including JNK and p38 MAPK, and SAPK phosphorylates the serine residues on PPAR to loss of activity. Hence, elevated levels of ROS and RNS could explain PPAR downregulation in obesity [107]. Moreover, NAD(+)-dependent histone deacetylase sirtuin-1 (SIRT1) expression is reduced in obesity, at least in part via iNOS-induced inactivation of SIRT1 $[140,141]$. Deficiency of SIRT1 in obesity leads to elevated inflammation characterized by increased mRNA expression of $\mathrm{NFKB}$ and pro-inflammatory cytokines in white adipose tissue [142].

In summary, activated IO and NS pathways are implicated in the pathogenesis of depression and metabolic comorbidities including insulin resistance. These metabolic disturbances activate IO and NS pathways and exacerbate dysfunctions in neuroplasticity, synaptic and neuronal signaling, apoptosis, and cell death in many psychiatric disorders. In the process, pro-inflammatory cytokines and oxidative/nitrosative stress, PPAR $\gamma$ inactivation, and SIRT1 deficiency are considered to be involved [107].

\subsubsection{Neurogenesis and Neuroplasticity}

Another possible shared mechanism that may cause both depression and diabetes is defective neurogenesis and synaptic plasticity. Considerable evidence suggests that insulin positively affects hippocampal synaptic and structural plasticity. Presynaptically, insulin increases basal neurotransmitter release and the density of dendritic spines [143]. Moreover, insulin promotes synaptic plasticity by modulating long-term potentiation (LTP) or long-term depression (LTD) at hippocampal synapses through a metaplastic mechanism [144]. The postsynaptic effects of insulin are mediated by PI3K activation [144] and increased membrane recruitment of $N$-methyl-D-aspartate (NMDA) receptors [84]. Insulin modulates glutamate receptor activity by enhancing phosphorylation of both NR2A and NR2B subunits of NMDA receptor [83] and clathrin-dependent endocytosis of the GluA1 subunit of a-amino-3-hydroxy-5-methyl-4-isoxazolepropionic acid (AMPA) receptors [145]. Downregulation of AMPA receptor activity in excitatory synapses of hippocampal CA1 neurons is fundamental for insulin-induced LTD [146]. Moreover, insulin may impinge on structural features of synapses, as revealed through enhanced dendritic spine formation by IRSp53 [147] and increased basal dendrites of CA1 pyramidal neurons by insulin-like growth factor (IGF)-1 stimulation [148]. Accordingly, mice rendered serum IGF-1 deficient by knocking out IGF1 show reduced density of glutamatergic synapses and disrupted LTP [149]. In addition, astrocytes, which play essential roles in synaptic plasticity, are also insulin responsive [150]. Furthermore, lack of proper central insulin signaling would result in dysfunctional hippocampal neurogenesis, which may play a role in the pathophysiology of depression and T2DM [7,151]. Energy metabolic and nutritional cues have been suggested as major physiological determinants of neural stem cell (NSC) fate and modulators of the whole neurogenic process. Insulin/IGF-1 cascade, mitochondrial activity, the $5^{\prime}$ AMP-activated protein kinase (AMPK)/mTOR axis, and the transcription regulators CREB and SIRT1 are well represented in the molecular networks that dictate neural-stem-cell self-renewal, migration, and differentiation [152]. Indeed, insulin may exert either trophic or harmful effects on NSCs depending on the timing and the duration of stimulation. Insulin and IGF-1 promote neurogenesis by modulating NSC proliferation, differentiation, and survival, but chronic hyper-activation of insulin/IGF-1 signaling cascades can cause premature depletion of the NSC reservoir [153-155]. Moreover, calorie restriction, which reduces 
plasma levels of glucose and insulin, enhances neurogenesis in the dentate gyrus, induces expression of brain-derived neurotrophic factor (BDNF), and regulates proliferation and self-renewal of NSCs and controls their reservoir by cell-autonomous mechanisms involving metabolic sensors such as SIRT1 and CREB in the hippocampus $[156,157]$. Conversely, ablation of the expression of genes encoding nuclear transcription factor forkhead box $\mathrm{O}$ transcription factor (FOXO), which mediate the inhibitory action of insulin or IGF-1 on neurogenesis and survival, induces premature neuronal differentiation and rapid depletion of NSCs [158] and aberrantly elevates the nutrient-dependent mTOR pathway, reducing self-renewal and accelerating premature differentiation of NSC [159]. Together, these findings emphasize the essential roles played by insulin in regulating neurogenesis, neuronal development, and synaptic plasticity.

\subsubsection{Hypothalamic-Pituitary-Adrenal Axis}

Another point that should be addressed is the allostatic load and the HPA axis, a key component mediating chronic psychological stress and depression or T2DM. Variations in the glucocorticoid (GC) level have been repeatedly reported in the blood of patients with depressive symptoms and T2DM, as compared to healthy controls $[160,161]$. Moreover, HPA axis dysregulation is among the most reliable of biological findings in depression and is implicated in the development of insulin resistance. However, the correlations of stress with diabetes and the metabolic effects of GC on the brain are still poorly understood $[162,163]$. GCs are major regulators of energy metabolism, playing key roles in the counter-regulatory responses and metabolic adaptations to the increased energy demand provoked by stress. In general, GCs mobilize energy substrates such as lipids and glucose, increasing their levels in systemic circulation [164]. Physiologically, GCs promote insulin secretion [165]; conversely, insulin activates the HPA axis and leads to an increase in GC levels and corticotropin releasing hormone (CRH) levels [166]. Increases in CRH by insulin are mediated through activation of the cyclic adenosine monophosphate (cAMP)/AMP protein kinase A (PKA) and PI3K/AKT pathways; this activation, in turn, affects $\mathrm{CRH}$ promoters, stimulates $\mathrm{CRH}$ gene transcription, and increases $\mathrm{CRH}$ levels [166].

Under chronic stress conditions, GC receptor resistance develops and disrupts HPA axis regulation [167]. The subsequent uninhibited release of GCs triggers physiological cascades that play a role in the pathophysiology of metabolic and psychiatric pathology, including insulin resistance and obesity [168]. In preclinical studies, chronic stress or long-term GC exposure led to depressive-like behavior as well as insulin resistance in rats, possibly mediated by the cAMP/CREB pathway and insulin signaling involving the signal transducer and activator of transcription 3 (STAT3) and PI3K-AKT-FOXO1 pathways damaged by inhibiting the activation of IRS2 and PI3K [169,170]. Moreover, administration of exogenous GC can induce an insulin-resistant brain state by altering gene expression of insulin [171]. Chronic GC exposure also can induce increased expression of JNK in the hippocampus, which is associated with insulin receptor-mediated inactivation of the Akt/glycogen synthase kinase (GSK) $3 \beta$ pathway, which leads to depressive symptoms [172]. While long-term GC exposure induces insulin resistance, insulin resistance can induce glucocorticoid receptor insensitivity and HPA axis dysregulation. One of the mechanisms by which insulin affects the HPA axis is in its effect on blood glucose [173]. When insulin does not effectively lower blood glucose, its effect on the HPA axis is diminished [166]. These results suggest that the bidirectional physiological link between depression and diabetes is likely to involve the HPA axis.

\subsubsection{Gastrointestinal Microbiome}

The accumulating knowledge suggests that disruptions to the gut microbiome can contribute to both metabolic and depressive disorders. Recent evidences indicate that gut microbes and insulin interact with each other. Reducing insulin resistance could maintain the homeostasis of gut microbiota and restore intestinal microbiome disorders [166]. Inversely, modulation of gut microbiota could improve glucose metabolism and insulin resistance by adjusting the microbiota-gut-brain 
axis [174]. Probiotics can modulate the HPA axis, inflammation, and neurotransmitters $[175,176]$. Indeed, gut microbiota modification can reduce depressive behavior through enhancing brain insulin signaling, decreasing inflammation, and modulating neurotransmitters and other neuroactive molecules such as BDNF, GABA, and tryptophan in affect-related brain structures including amygdala and nucleus accumbens $[177,178]$. Moreover, insulin sensitizing agents probably have both direct and indirect effects on gut bacteria. Studies in rodents and humans tend to agree that metformin treatment increases the relative abundance of bacteria which produce short chain fatty acid and stimulate the secretion of GLP-1 and GLP-2, and thereby increasing insulin and adiponectin expression, contributing to enhanced insulin sensitivity $[179,180]$. The relative abundance of genus Akkermansia, mucin-degrading bacteria, increases in metformin-treated mice on a high-fat diet (HFD). This positive influence is probably due to metformin action on mucin-producing goblet cells in the intestine which underlie the improved glucose profiles associated with Akkermansia [181]. GLP-1RA including liraglutide can also alter gut microbiota. Substantial rearrangement of the bacterial structure was observed in mice treated with liraglutide [182]. The authors postulated that GLP-1RA delays the gut transit time and gastric emptying rate, and it could modify the gut lumen internal environment and thus affect microbiota composition. Additionally, this may be because PPAR $\gamma$ agonists have anti-bacterial activity, and they may indirectly affect gut bacteria [183]. Bai et al. [184] showed that pioglitazone administration in high fat-fed rats reduces the abundance of proteobacteria, which seems to correlate with the decrease in pro-inflammatory cytokines and plasma endotoxin levels. In summary, the main effect of insulin sensitizing agents is thought to be on the microbiome composition, basically increasing the short chain fatty acid-producing bacteria responsible for losing weight and suppressing inflammation [180].

\subsection{Linking Clinical Evidence and Pathophysiology: Possible Mechanisms of Antidepressant Effects of Anti-Hyperglycemic Agents}

As noted above, to date, insulin-based medications have shown disappointing results. The lack of significant antidepressant effect from insulin-based medications suggests that insulin resistance may disrupt the first steps of insulin signaling by the insulin receptor, and that approaches that bypass the first steps of insulin signaling might show better results [7]. Clinical trials and meta-analyses support the antidepressant effect of PPAR $\gamma$ receptor agonists, and studies with metformin and liraglutide have yielded discrepant results.

Liraglutide is an incretin analog that acts as an agonist to GLP-1 receptor. GLP-1, which is an endogenous incretin hormone released after food intake, is mainly secreted by intestinal L cells, but also by other organs including the CNS. The receptors of GLP-1 are expressed in the pancreas and peripheral tissues including the heart, kidney, lung, and gastrointestinal tract, as well as various brain regions such as the brainstem, arcuate nucleus, area postrema, hypothalamus, nucleus tractus, and vagal afferents $[185,186]$. Activation of GLP-1 receptor signaling promotes the facilitation of glucose utilization through glucose-induced insulin release and suppression of glucagon release from the pancreas [33]. It is also well established that GLP-1 acts as a neuropeptide that provides glycemic homeostasis [187] and appetite/food intake control [188]. GLP-1, as well as its analogues, can readily cross the BBB and exert various physiological effects [189]. GLP-1 is also able to facilitate glucose transport across the BBB, which is crucial in the homeostasis of brain metabolism [190]. Additionally, growing evidence shows that GLP-1 modulates inflammation and has neuroprotective and neurotrophic effects whose relationship to the pathophysiology of depression is widely accepted [191-193]. The important downstream signaling pathway activated by the GLP-1 receptor is the Akt pathway [194], which has the ability to phosphorylate proteins regulating neurogenesis, neuronal development, and synaptic plasticity such as GSK3 $\beta$, FOXO1, and mTOR (see Section 5.1.3). Moreover, it is reported that GLP-1 signaling regulates dopamine release in striatal neurons $[195,196]$. As central insulin and dopamine action are interlinked and have impacts on mood, reward, and food intake [197], the dopaminergic system could become compromised under brain insulin resistance. Indeed, in animal models of 
neurodegenerative disease, GLP-1RAs were able to protect dopaminergic neurons and improve neuropathological features and cognitive functions [198].

However, in an RCT, liraglutide did not improve depressive symptoms despite improvement in metabolic parameters [52]. Moreover, although an open-label study reported significant improvements in HDRS scores and cognitive performance by adjuvant liraglutide administration in subjects with mood disorder [33], the antidepressant effects are not clear because that study included subjects with cognitive impairment at baseline (below average performance in the Trail Making Test-B) and mild depressive symptoms (mean HDRS score $=12.6$ ). One possibility that should not be overlooked is the moderating role of cognitive impairment in the effect of liraglutide on depressive symptoms. Cognitive dysfunction is known to be a psychopathological domain that is relevant in both diabetes and depression. Furthermore, GLP-1RA, including liraglutide, have pro-cognitive effects via molecular pathways and contribute to the pathophysiology of depression and to antidepressant efficacy; GLP-1RA has direct roles in the neurogenesis of the dentate gyrus [199], beneficial actions on mitochondria via the PI3K/Akt pathway and upregulation of antiapoptotic proteins such as Bcl-2, and neuroprotective effects by decreasing neuroinflammation and improving control of synaptic plasticity [194]. However, although different therapeutic strategies including liraglutide can show pro-cognitive effects in depressed patients, research to date has not been designed to distinguish direct pro-cognitive effects from indirect effects on cognition via improvements in mood [200,201]. Given that cognitive improvement was positively correlated with baseline metabolic disturbance, including insulin resistance and body mass index (BMI) in a previous study [33], it is possible that certain subpopulations in whom the dominant psychopathology of depression takes the form of cognitive deficits with underlying metabolic impairment would be more responsive to an intervention that targets glucose and insulin metabolism [202].

Metformin is currently the first-line pharmacological agent for the management of T2DM. Although the mechanisms by which it improves insulin sensitivity are not completely understood, metformin has traditionally been thought to act on the liver to control blood glucose levels by reducing hepatic glucose production and enhancing insulin sensitivity through several molecular pathways including mitochondrial control and AMPK activation [203]. Metformin could also affect glucose metabolism via actions on the intestines such as increasing glucose utilization by the gut, increasing GLP-1 secretion, altering the intestinal microbiome, and suppressing hepatic glucose production via the nucleus tractus solitarius and vagal efferents through AMPK and GLP-1 receptor activation [203]. In the CNS, metformin exercises its effects through many molecular pathways and mechanisms, although conflicting results have been found. Experimentally, metformin has been shown to act as an antidepressant, at least in part, by regulating AMPK signaling, a key enzyme for cellular energy homeostasis. Moreover, a decrease in phosphorylated AMPK (pAMPK) is closely associated with depression-like behaviors in mice under chronic stress [204]. Metformin inhibits mitochondrial respiratory chain complex I, thereby increasing the AMP/ATP ratio, and this lack of energy leads to activation of AMPK. Metformin can also activate AMPK by accumulation of reactive nitrogen species, in turn stimulating the c-Src/PI3K pathway and generating molecules inside the cell to promote AMPK activation [205]. Previous research has suggested that AMPK activation can increase the expression of BDNF, which plays a vital role in the maintenance of synaptic plasticity and depression/anti-depression by activating CREB and Akt/GSK3 signaling pathways [206] and mTOR signaling [207], and by regulating DNA hydroxymethylation via the AMPK/Tet2 pathway [204].

Metformin also has antioxidant properties and regulatory effects on immune response. Although it is not clear whether metformin is able to cross the BBB to reach the brain and exert a direct effect on the CNS, it seems that metformin may cross the BBB and play a central role as Lv et al. reported [208]. As mentioned above, metformin inhibits mitochondrial respiratory chain complex I, which reduces ROS levels, and reduces the production of NO, prostaglandin E2 (PGE2), and pro-inflammatory cytokines (IL-1 $\beta$, IL-6, and TNF- $\alpha$ ) [209]. As compelling research has indicated a role for systemic inflammation and oxidative stress in the pathophysiology of MDD [124,210,211], better understanding of the possible 
antidepressant effects of metformin would provide insights into the pathophysiology of depression. One of the key factors determining the antioxidative effect of metformin is nuclear factor erythroid 2-related factor 2 (Nrf2). Metformin activates Nrf2, a transcription factor that regulates the expression of multiple antioxidant genes, in an AMPK-dependent manner [212]. The imbalance between ROS and antioxidative defenses leads to dysregulation of brain functions and abnormalities in neuronal signaling, and these have been shown to be correlated with the pathogenesis and progression of depression [126]. Several studies have reported that metformin attenuates elevated MDA levels and restores levels of GSH in states of imbalanced oxidation [212]. Moreover, a notable number of studies have demonstrated a role for Nrf2 as a key element in modulation of inflammatory and cell-mediated immune processes. In the brain, Nrf2 is a key regulator in reducing inflammatory damage, and the absence of Nrf2 may induce more aggressive inflammation through activation of the NFKB pathway [213]. Indeed, some studies have identified possible antidepressant effects of Nrf2 activators [214]. Additionally, as described above, the antidepressant-like effect of metformin may be associated with serotonin system and its projection to hippocampus [91]. Furthermore, metformin can decrease the expression of pro-inflammatory cytokines including IL- $1 \beta$ and IL- 6 regardless of diabetes status $[215,216]$ and reduce levels of pro-inflammatory cytokines which result in increased bioavailability of serotonin through regulation of multiple pathways including the tryptophan/kynurenine system [217-219]. In summary, the possible antidepressant effect of metformin supports the involvement of inflammation and oxidative stress in depression via diverse signaling molecules and pathways including Nrf2, pro-inflammatory cytokines and the AMPK/BDNF and NFKB pathways. The mechanisms of action of metformin on depression need further validation.

PPAR $\gamma$ agonists, also named thiazolidinediones, have been relatively well investigated and supported as potential candidates for the treatment of depression. PPAR $\gamma$ agonists have insulin sensitizing properties and are commonly used for the treatment of T2DM and MetS. These agents are potent activators of PPAR $\gamma$, one of three subtypes of PPARs (others are PPAR $\alpha$ and PPAR $\beta / \delta$ ), which are members of the nuclear receptor superfamily [220]. Upon ligand binding, PPARs translocate into the nucleus and regulate gene expression in a variety of processes including lipid and glucose metabolism, inflammation, atherosclerotic plaque formation, vascular tone, angiogenesis, cellular differentiation, myelinogenesis, glial cell maturation, and fertility [221]. PPAR $\gamma$ receptors are highly expressed in adipose tissue and regulate genes that control cellular energy homeostasis (see Section 5.1.2); their activation is engaged in multiple roles including differentiation of adipocytes, expression of mitochondrial uncoupling proteins, downregulation of leptin, and interaction with multiple genes that control insulin sensitivity [221,222]. Accordingly, PPAR $\gamma$ agonists have been shown to decrease visceral fat, reduce inflammation, and increase insulin sensitivity [223,224]. Moreover, PPAR $\gamma$ agonists are also able to cross the BBB effectively, exerting anti-inflammatory properties and improving insulin resistance in the brain [58]. In addition, the PPAR $\gamma$ agonists have been shown to improve insulin receptor signaling dysfunction by increasing neuronal insulin-stimulated Akt/PKB activation and to improve insulin-induced synaptic plasticity and reverse mitochondrial dysfunction during mitochondrial oxidative stress [21,225]. The antidepressant-like effect of PPAR $\gamma$ agonists may be mediated by monoaminergic neurotransmission. An animal study showed that treating obese animals with PPAR $\gamma$ agonists ameliorated depressive-like behavior [226]. This study used a diabetic mouse strain $(\mathrm{db} / \mathrm{db})$ which harbors an autosomal recessive point mutation in gene encoding for the long isoform of the leptin receptor. $\mathrm{db} / \mathrm{db}$ mice mimic clinical type-2 diabetic conditions such as obesity, hyperglycemia, hyperinsulinemia, hyperphagia, polydypsia, polyurea, impotency, pancreatic $\beta$-cell hyperplasia and hypertrophy [226,227], and they also show impairments in dopamine metabolism in the amygdala [228]. The results from this study indicate that insulin action improves mood via modulation of dopamine signaling. Additionally, the literatures [229-231] suggested that PPAR- $\gamma$ activity could be stimulated by serotonergic neurotransmission. Indeed, in fat cells, serotonin leads to the activation of PPAR- $\gamma$ responsive genes and enhances lipid accumulation [32]. Consequently, the association between antidepressant effect and the activity of the PPAR- $\gamma$ pathway could be modulated by serotonin system functioning. Recently, Hegazy et al. [232] reported that high fat diet induced obesity was 
associated with reduced catechol O-methyltransferase (COMT) expression with a concomitant increase in plasma catecholamines as well as metabolic effects such as glucose intolerance, derangement of the lipid profile, and increased systolic blood pressure. Pioglitazone treatment ameliorated the HFD-induced metabolic changes and up-regulated COMT expression with a subsequent reduction in plasma catecholamines levels.

Research addressing whether the beneficial effect of PPAR $\gamma$ agonists on depressive symptoms is correlated with changes in insulin resistance level has been equivocal. Some studies have found no correlation [42,46,51], whereas others have reported marginal [44] or positive results [21]. Alternatively, pathways other than insulin resistance may mediate the antidepressant properties of PPAR $\gamma$ agonists. The improvement in depression correlated with normalization of pro-inflammatory biomarkers, including pro-inflammatory adipokines (leptin) or cytokine (IL-6), suggests a role for inflammatory pathways and intriguing links between PPAR $\gamma$ activation, depression, and inflammation $[45,51]$.

\section{Conclusions}

Disappointingly, evidence suggest that treatment of anti-hyperglycemic agents to depression have shown limited success. Although the antidepressant effects of PPAR $\gamma$ receptor agonists were supported in multiple clinical trials and meta-analyses, the antidepressant efficacy of anti-hyperglycemic agents so far has been equivocal. Since a bidirectional relationship between insulin resistance and depression is supported by several bodies of evidence, it is important to clarify the potential association of these two conditions and explore their common pathophysiological basis. Evidence from investigations of the antidepressant properties of repurposed anti-hyperglycemic agents may provide new insight into the role of brain insulin signaling in the pathophysiology of depression. In the present article, we reviewed the antidepressant properties of anti-hyperglycemic agents including metformin, PPAR $\gamma$ receptor agonists, and GLP-1RA and addressed the underlying mechanisms of these properties. However, although clinical trials have offered some encouraging results, few studies have addressed a sufficient number of biomarkers to enhance our understanding of the molecular and cellular mechanisms involved in the pathophysiology of depression and the antidepressant properties of anti-hyperglycemic agents. Additionally, other important issues are not addressed in this review. Insulin-sensitizing agents may improve the response to antidepressant drugs. Differential impact of changes in central versus peripheral insulin signaling system during pathological conditions and pharmacotherapy with agents targeting insulin receptor should also considered to gain a better understanding of the antidepressant effects of anti-hyperglycemic agents. Unraveling the relationships between depression and impaired insulin signaling could be a matter of great importance as we pursue an understanding of the associated pathophysiology and explore alternative treatment options. Further studies focusing on this issue are warranted.

Author Contributions: All authors made substantial intellectual contributions to the conception and design of the study. W.-M.B. conceived the study design and supervised the planning, writing, and editing of the report. H.K.L. supervised writing, editing, and proofreading of the paper. Y.S.W. and S.-M.W. carried out the literature search and wrote and edited the manuscript. All authors contributed to manuscript preparation and revision. All authors have read and agreed to the published version of the manuscript.

Funding: This research received no external funding.

Conflicts of Interest: The authors declare no conflict of interest. The funders had no role in the design of the study; in the collection, analyses, or interpretation of data; in the writing of the manuscript, or in the decision to publish the results.

\section{Abbreviations}

$\begin{array}{ll}\text { T2DM } & \text { Type } 2 \text { diabetes } \\ \text { GLP-1RA } & \text { Glucagon like peptide-1 receptor agonists } \\ \text { PPAR } & \text { Peroxisome proliferator-activated receptor } \\ \text { IR } & \text { Insulin receptor } \\ \text { IRS } & \text { Insulin receptor substrate } \\ \text { PI3K } & \text { Phosphatidylinositol 3-kinase }\end{array}$




\begin{tabular}{|c|c|}
\hline Akt & Serine/threonine kinase \\
\hline MAPK & Mitogen-activated protein kinase \\
\hline ERK & Extracellular signal-regulated kinase \\
\hline GLP-1 & Glucagon-like peptide-1 \\
\hline MDD & Major depressive disorder \\
\hline GDS & Geriatric Depression Scale \\
\hline HADS & Hospital Anxiety and Depression Scale \\
\hline HPA & Hypothalamic-Pituitary-Adrenal \\
\hline TSST & Trier Social Stress Test \\
\hline MADRS & Montgomery Åsberg Depression Rating Scale \\
\hline PANAS & Positive and Negative Affect Schedule \\
\hline BDI & Beck Depression Inventory \\
\hline RCT & Randomized clinical trial \\
\hline HDRS & Hamilton Depression Rating Scale \\
\hline PCOS & Polycystic ovarian syndrome \\
\hline MetS & Metabolic syndrome \\
\hline IDS & Inventory of Depressive Symptomatology \\
\hline HOMA-IR & Homeostatic model assessment of insulin resistance \\
\hline QIDS & Quick Inventory of Depressive Symptoms \\
\hline OR & Odds ratio \\
\hline $\mathrm{CI}$ & Confidence interval \\
\hline NIRKO & Neuronal-specific knockout of insulin receptor \\
\hline BCAA & Branched chain amino acids \\
\hline LAT & Large neutral amino acid transporter \\
\hline IO and NS & Immune/Inflammatory and Oxidative, and Nitrosative Stres \\
\hline IL & Interleukin \\
\hline TNF & Tumor necrosis factor \\
\hline CRP & C-reactive protein \\
\hline $\mathrm{CNS}$ & central nervous system \\
\hline IDO & Indolemaine 2,3-dioxygenase \\
\hline SERT & serotonin transporter \\
\hline $\mathrm{IKK} \beta$ & IкB kinase $\beta$ \\
\hline NKкB & nuclear factor $\mathrm{kB}$ \\
\hline JNK & c-Jun $N$-terminal kinase \\
\hline BBB & Blood-Brain barrier \\
\hline HDL-c & High-density lipoprotein cholesterol \\
\hline MDA & Malondialdehyde \\
\hline CAT & Catalase \\
\hline SOD & Superoxide dismutase \\
\hline GSH & Glutathione \\
\hline PON1 & Paraoxonase 1 \\
\hline ROS & Reactive oxygen species \\
\hline $\mathrm{NO}$ & Nitric oxide \\
\hline NOS & Nitric oxide synthase \\
\hline SAPK & Stress-activated kinases \\
\hline LTP & Long-term potentiation \\
\hline LTD & Long-term depression \\
\hline NMDA & $\mathrm{N}$-methyl-D-aspartate \\
\hline AMPA & a-amino-3-hydroxy-5-methyl-4-isoxazolepropionic acid \\
\hline IGF & Insulin-like growth factor \\
\hline BDNF & Brain-derived neurotrophic factor \\
\hline FOXO & Forkhead box $\mathrm{O}$ transcription factor \\
\hline GC & Glucocorticoid \\
\hline $\mathrm{CRH}$ & Corticotropin releasing hormone \\
\hline cAMP & Cyclic adenosine monophosphate \\
\hline PKA & Protein kinase A \\
\hline STAT & Signal transducer and activator of transcription \\
\hline GSK & Glycogen synthase kinase \\
\hline Nrf2 & Nuclear factor erythroid 2-related factor 2 \\
\hline COMT & Catechol O-methyltransferase \\
\hline
\end{tabular}




\section{References}

1. Kessler, R.C.; Bromet, E.J. The epidemiology of depression across cultures. Annu. Rev. Public Health 2013, 34, 119-138. [CrossRef]

2. Souery, D.; Papakostas, G.I.; Trivedi, M.H. Treatment-resistant depression. J. Clin. Psychiatry 2006, 67 (Suppl. 6), 16-22. [PubMed]

3. Seo, J.S.; Bahk, W.M.; Wang, H.R.; Woo, Y.S.; Park, Y.M.; Jeong, J.H.; Kim, W.; Shim, S.H.; Lee, J.G.; Jon, D.I.; et al. Korean Medication Algorithm for Depressive Disorders 2017: Third Revision. Clin. Psychopharmacol. Neurosci. 2018, 16, 67-87. [CrossRef] [PubMed]

4. Kennedy, S.H.; Lam, R.W.; McIntyre, R.S.; Tourjman, S.V.; Bhat, V.; Blier, P.; Hasnain, M.; Jollant, F.; Levitt, A.J.; MacQueen, G.M.; et al. Canadian Network for Mood and Anxiety Treatments (CANMAT) 2016 Clinical Guidelines for the Management of Adults with Major Depressive Disorder: Section 3. Pharmacological Treatments. Can. J. Psychiatry 2016, 61, 540-560. [CrossRef] [PubMed]

5. Cleare, A.; Pariante, C.M.; Young, A.H.; Anderson, I.M.; Christmas, D.; Cowen, P.J.; Dickens, C.; Ferrier, I.N.; Geddes, J.; Gilbody, S.; et al. Evidence-based guidelines for treating depressive disorders with antidepressants: A revision of the 2008 British Association for Psychopharmacology guidelines. J. Psychopharmacol. 2015, 29, 459-525. [CrossRef] [PubMed]

6. Bauer, M.; Pfennig, A.; Severus, E.; Whybrow, P.C.; Angst, J.; Moller, H.J.; World Federation of Societies of Biological Psychiatry. Task Force on Unipolar Depressive, D. World Federation of Societies of Biological Psychiatry (WFSBP) guidelines for biological treatment of unipolar depressive disorders, part 1: Update 2013 on the acute and continuation treatment of unipolar depressive disorders. World J. Biol. Psychiatry 2013, 14, 334-385. [CrossRef]

7. Lyra, E.S.N.M.; Lam, M.P.; Soares, C.N.; Munoz, D.P.; Milev, R.; De Felice, F.G. Insulin Resistance as a Shared Pathogenic Mechanism Between Depression and Type 2 Diabetes. Front. Psychiatry 2019, 10, 57. [CrossRef]

8. Watson, K.; Nasca, C.; Aasly, L.; McEwen, B.; Rasgon, N. Insulin resistance, an unmasked culprit in depressive disorders: Promises for interventions. Neuropharmacology 2018, 136, 327-334. [CrossRef]

9. Kan, C.; Silva, N.; Golden, S.H.; Rajala, U.; Timonen, M.; Stahl, D.; Ismail, K. A systematic review and meta-analysis of the association between depression and insulin resistance. Diabetes Care 2013, 36, 480-489. [CrossRef]

10. Ali, S.; Stone, M.A.; Peters, J.L.; Davies, M.J.; Khunti, K. The prevalence of co-morbid depression in adults with Type 2 diabetes: A systematic review and meta-analysis. Diabet. Med. 2006, 23, 1165-1173. [CrossRef]

11. Eaton, W.W.; Armenian, H.; Gallo, J.; Pratt, L.; Ford, D.E. Depression and risk for onset of type II diabetes. A prospective population-based study. Diabetes Care 1996, 19, 1097-1102. [CrossRef]

12. Mezuk, B.; Eaton, W.W.; Albrecht, S.; Golden, S.H. Depression and type 2 diabetes over the lifespan: A meta-analysis. Diabetes Care 2008, 31, 2383-2390. [CrossRef] [PubMed]

13. Yu, M.; Zhang, X.; Lu, F.; Fang, L. Depression and Risk for Diabetes: A Meta-Analysis. Can. J. Diabetes 2015, 39, 266-272. [CrossRef] [PubMed]

14. Cha, D.S.; Best, M.W.; Bowie, C.R.; Gallaugher, L.A.; Woldeyohannes, H.O.; Soczynska, J.K.; Lewis, G.; MacQueen, G.; Sahakian, B.J.; Kennedy, S.H.; et al. A randomized, double-blind, placebo-controlled, crossover trial evaluating the effect of intranasal insulin on cognition and mood in individuals with treatment-resistant major depressive disorder. J. Affect. Disord. 2017, 210, 57-65. [CrossRef] [PubMed]

15. Kleinridders, A.; Cai, W.; Cappellucci, L.; Ghazarian, A.; Collins, W.R.; Vienberg, S.G.; Pothos, E.N.; Kahn, C.R. Insulin resistance in brain alters dopamine turnover and causes behavioral disorders. Proc. Natl. Acad. Sci. USA 2015, 112, 3463-3468. [CrossRef] [PubMed]

16. Chaudhury, D.; Liu, H.; Han, M.H. Neuronal correlates of depression. Cell Mol. Life Sci. 2015, 72, 4825-4848. [CrossRef] [PubMed]

17. Taniguchi, C.M.; Emanuelli, B.; Kahn, C.R. Critical nodes in signalling pathways: Insights into insulin action. Nat. Rev. Mol. Cell Biol. 2006, 7, 85-96. [CrossRef]

18. Hill, A.S.; Sahay, A.; Hen, R. Increasing Adult Hippocampal Neurogenesis is Sufficient to Reduce Anxiety and Depression-Like Behaviors. Neuropsychopharmacology 2015, 40, 2368-2378. [CrossRef]

19. Rosenblat, J.D.; McIntyre, R.S.; Alves, G.S.; Fountoulakis, K.N.; Carvalho, A.F. Beyond Monoamines-Novel Targets for Treatment-Resistant Depression: A Comprehensive Review. Curr. Neuropharmacol. 2015, 13, 636-655. [CrossRef] 
20. Williams, J.M.; Owens, W.A.; Turner, G.H.; Saunders, C.; Dipace, C.; Blakely, R.D.; France, C.P.; Gore, J.C.; Daws, L.C.; Avison, M.J.; et al. Hypoinsulinemia regulates amphetamine-induced reverse transport of dopamine. PLoS Biol. 2007, 5, e274. [CrossRef]

21. Kemp, D.E.; Ismail-Beigi, F.; Ganocy, S.J.; Conroy, C.; Gao, K.; Obral, S.; Fein, E.; Findling, R.L.; Calabrese, J.R. Use of insulin sensitizers for the treatment of major depressive disorder: A pilot study of pioglitazone for major depression accompanied by abdominal obesity. J. Affect. Disord. 2012, 136, 1164-1173. [CrossRef] [PubMed]

22. Grillo, C.A.; Piroli, G.G.; Kaigler, K.F.; Wilson, S.P.; Wilson, M.A.; Reagan, L.P. Downregulation of hypothalamic insulin receptor expression elicits depressive-like behaviors in rats. Behav. Brain Res. 2011, 222, 230-235. [CrossRef] [PubMed]

23. Cai, W.; Xue, C.; Sakaguchi, M.; Konishi, M.; Shirazian, A.; Ferris, H.A.; Li, M.E.; Yu, R.; Kleinridders, A.; Pothos, E.N.; et al. Insulin regulates astrocyte gliotransmission and modulates behavior. J. Clin. Investig. 2018, 128, 2914-2926. [CrossRef] [PubMed]

24. Rotte, M.; Baerecke, C.; Pottag, G.; Klose, S.; Kanneberg, E.; Heinze, H.J.; Lehnert, H. Insulin affects the neuronal response in the medial temporal lobe in humans. Neuroendocrinology 2005, 81, 49-55. [CrossRef]

25. Shemesh, E.; Rudich, A.; Harman-Boehm, I.; Cukierman-Yaffe, T. Effect of intranasal insulin on cognitive function: A systematic review. J. Clin. Endocrinol. Metab. 2012, 97, 366-376. [CrossRef] [PubMed]

26. Sharma, S.; Fulton, S. Diet-induced obesity promotes depressive-like behaviour that is associated with neural adaptations in brain reward circuitry. Int. J. Obes. 2013, 37, 382-389. [CrossRef] [PubMed]

27. Dutheil, S.; Ota, K.T.; Wohleb, E.S.; Rasmussen, K.; Duman, R.S. High-Fat Diet Induced Anxiety and Anhedonia: Impact on Brain Homeostasis and Inflammation. Neuropsychopharmacology 2016, 41, 1874-1887. [CrossRef]

28. Zemdegs, J.; Quesseveur, G.; Jarriault, D.; Penicaud, L.; Fioramonti, X.; Guiard, B.P. High-fat diet-induced metabolic disorders impairs 5-HT function and anxiety-like behavior in mice. Br. J. Pharmacol. 2016, 173, 2095-2110. [CrossRef]

29. Gupta, D.; Kurhe, Y.; Radhakrishnan, M. Antidepressant effects of insulin in streptozotocin induced diabetic mice: Modulation of brain serotonin system. Physiol. Behav. 2014, 129, 73-78. [CrossRef]

30. Andre, C.; Dinel, A.L.; Ferreira, G.; Laye, S.; Castanon, N. Diet-induced obesity progressively alters cognition, anxiety-like behavior and lipopolysaccharide-induced depressive-like behavior: Focus on brain indoleamine 2,3-dioxygenase activation. Brain Behav. Immun. 2014, 41, 10-21. [CrossRef]

31. Hassan, A.M.; Mancano, G.; Kashofer, K.; Frohlich, E.E.; Matak, A.; Mayerhofer, R.; Reichmann, F.; Olivares, M.; Neyrinck, A.M.; Delzenne, N.M.; et al. High-fat diet induces depression-like behaviour in mice associated with changes in microbiome, neuropeptide Y, and brain metabolome. Nutr. Neurosci. 2019, 22, 877-893. [CrossRef] [PubMed]

32. Colle, R.; de Larminat, D.; Rotenberg, S.; Hozer, F.; Hardy, P.; Verstuyft, C.; Feve, B.; Corruble, E. Pioglitazone could induce remission in major depression: A meta-analysis. Neuropsychiatr. Dis. Treat. 2017, 13, 9-16. [CrossRef] [PubMed]

33. Mansur, R.B.; Ahmed, J.; Cha, D.S.; Woldeyohannes, H.O.; Subramaniapillai, M.; Lovshin, J.; Lee, J.G.; Lee, J.H.; Brietzke, E.; Reininghaus, E.Z.; et al. Liraglutide promotes improvements in objective measures of cognitive dysfunction in individuals with mood disorders: A pilot, open-label study. J. Affect. Disord. 2017, 207, 114-120. [CrossRef] [PubMed]

34. Sharma, A.N.; Ligade, S.S.; Sharma, J.N.; Shukla, P.; Elased, K.M.; Lucot, J.B. GLP-1 receptor agonist liraglutide reverses long-term atypical antipsychotic treatment associated behavioral depression and metabolic abnormalities in rats. Metab. Brain Dis. 2015, 30, 519-527. [CrossRef] [PubMed]

35. Reza, M.; Taylor, C.D.; Towse, K.; Ward, J.D.; Hendra, T.J. Insulin improves well-being for selected elderly type 2 diabetic subjects. Diabetes Res. Clin. Pract. 2002, 55, 201-207. [CrossRef]

36. Hendra, T.J.; Taylor, C.D. A randomised trial of insulin on well-being and carer strain in elderly type 2 diabetic subjects. J. Diabetes Complicat. 2004, 18, 148-154. [CrossRef]

37. Benedict, C.; Hallschmid, M.; Hatke, A.; Schultes, B.; Fehm, H.L.; Born, J.; Kern, W. Intranasal insulin improves memory in humans. Psychoneuroendocrinology 2004, 29, 1326-1334. [CrossRef]

38. Ackermann, R.T.; Edelstein, S.L.; Narayan, K.M.; Zhang, P.; Engelgau, M.M.; Herman, W.H.; Marrero, D.G.; Diabetes Prevention Program Research Group. Changes in health state utilities with changes in body mass in the Diabetes Prevention Program. Obesity 2009, 17, 2176-2181. [CrossRef] 
39. Guo, M.; Mi, J.; Jiang, Q.M.; Xu, J.M.; Tang, Y.Y.; Tian, G.; Wang, B. Metformin may produce antidepressant effects through improvement of cognitive function among depressed patients with diabetes mellitus. Clin. Exp. Pharmacol. Physiol. 2014, 41, 650-656. [CrossRef]

40. Krysiak, R.; Drosdzol-Cop, A.; Skrzypulec-Plinta, V.; Okopien, B. Sexual Functioning and Depressive Symptoms in Women with Diabetes and Prediabetes Receiving Metformin Therapy: A Pilot Study. Exp. Clin. Endocrinol. Diabetes 2017, 125, 42-48. [CrossRef]

41. Jamilian, H.; Jamilian, M.; Foroozanfard, F.; Afshar Ebrahimi, F.; Bahmani, F.; Asemi, Z. Comparison of myo-inositol and metformin on mental health parameters and biomarkers of oxidative stress in women with polycystic ovary syndrome: A randomized, double-blind, placebo-controlled trial. J. Psychosom. Obstet. Gynaecol. 2018, 39, 307-314. [CrossRef] [PubMed]

42. Rasgon, N.L.; Kenna, H.A.; Williams, K.E.; Powers, B.; Wroolie, T.; Schatzberg, A.F. Rosiglitazone add-on in treatment of depressed patients with insulin resistance: A pilot study. Sci. World J. 2010, 10, 321-328. [CrossRef]

43. Sepanjnia, K.; Modabbernia, A.; Ashrafi, M.; Modabbernia, M.J.; Akhondzadeh, S. Pioglitazone adjunctive therapy for moderate-to-severe major depressive disorder: Randomized double-blind placebo-controlled trial. Neuropsychopharmacology 2012, 37, 2093-2100. [CrossRef]

44. Kashani, L.; Omidvar, T.; Farazmand, B.; Modabbernia, A.; Ramzanzadeh, F.; Tehraninejad, E.S.; Ashrafi, M.; Tabrizi, M.; Akhondzadeh, S. Does pioglitazone improve depression through insulin-sensitization? Results of a randomized double-blind metformin-controlled trial in patients with polycystic ovarian syndrome and comorbid depression. Psychoneuroendocrinology 2013, 38, 767-776. [CrossRef] [PubMed]

45. Kemp, D.E.; Schinagle, M.; Gao, K.; Conroy, C.; Ganocy, S.J.; Ismail-Beigi, F.; Calabrese, J.R. PPAR-gamma agonism as a modulator of mood: Proof-of-concept for pioglitazone in bipolar depression. CNS Drugs 2014, 28, 571-581. [CrossRef] [PubMed]

46. Roohafza, H.; Shokouh, P.; Sadeghi, M.; Alikhassy, Z.; Sarrafzadegan, N. A Possible Role for Pioglitazone in the Management of Depressive Symptoms in Metabolic Syndrome Patients (EPICAMP Study): A Double Blind, Randomized Clinical Trial. Int. Sch. Res. Not. 2014, 2014, 697617. [CrossRef]

47. Lin, K.W.; Wroolie, T.E.; Robakis, T.; Rasgon, N.L. Adjuvant pioglitazone for unremitted depression: Clinical correlates of treatment response. Psychiatry Res. 2015, 230, 846-852. [CrossRef]

48. Hu, Y.; Xing, H.; Dong, X.; Lu, W.; Xiao, X.; Gao, L.; Cui, M.; Chen, J. Pioglitazone is an effective treatment for patients with post-stroke depression combined with type 2 diabetes mellitus. Exp. Ther. Med. 2015, 10, 1109-1114. [CrossRef]

49. Zeinoddini, A.; Sorayani, M.; Hassanzadeh, E.; Arbabi, M.; Farokhnia, M.; Salimi, S.; Ghaleiha, A.; Akhondzadeh, S. Pioglitazone adjunctive therapy for depressive episode of bipolar disorder: A randomized, double-blind, placebo-controlled trial. Depress. Anxiety 2015, 32, 167-173. [CrossRef]

50. NINDS Exploratory Trials in Parkinson Disease (NET-PD) FS-ZONE Investigators. Pioglitazone in early Parkinson's disease: A phase 2, multicentre, double-blind, randomised trial. Lancet Neurol. 2015, 14, 795-803. [CrossRef]

51. Aftab, A.; Kemp, D.E.; Ganocy, S.J.; Schinagle, M.; Conroy, C.; Brownrigg, B.; D’Arcangelo, N.; Goto, T.; Woods, N.; Serrano, M.B.; et al. Double-blind, placebo-controlled trial of pioglitazone for bipolar depression. J. Affect. Disord. 2019, 245, 957-964. [CrossRef] [PubMed]

52. De Wit, H.M.; Vervoort, G.M.; Jansen, H.J.; de Grauw, W.J.; de Galan, B.E.; Tack, C.J. Liraglutide reverses pronounced insulin-associated weight gain, improves glycaemic control and decreases insulin dose in patients with type 2 diabetes: A 26 week, randomised clinical trial (ELEGANT). Diabetologia 2014, 57, 1812-1819. [CrossRef] [PubMed]

53. Bai, X.; Liu, Z.; Li, Z.; Yan, D. The association between insulin therapy and depression in patients with type 2 diabetes mellitus: A meta-analysis. BMJ Open 2018, 8, e020062. [CrossRef]

54. Roy, A.; Campbell, M.K. A unifying framework for depression: Bridging the major biological and psychosocial theories through stress. Clinical and investigative medicine. Med. Clin. Exp. 2013, 36, 170-190. [CrossRef]

55. Bohringer, A.; Schwabe, L.; Richter, S.; Schachinger, H. Intranasal insulin attenuates the hypothalamic-pituitary-adrenal axis response to psychosocial stress. Psychoneuroendocrinology 2008, 33, 1394-1400. [CrossRef] [PubMed]

56. Moulton, C.D.; Hopkins, C.W.P.; Ismail, K.; Stahl, D. Repositioning of diabetes treatments for depressive symptoms: A systematic review and meta-analysis of clinical trials. Psychoneuroendocrinology 2018, 94, 91-103. [CrossRef] [PubMed] 
57. Benedict, C.; Frey, W.H., 2nd; Schioth, H.B.; Schultes, B.; Born, J.; Hallschmid, M. Intranasal insulin as a therapeutic option in the treatment of cognitive impairments. Exp. Gerontol. 2011, 46, 112-115. [CrossRef]

58. Hamer, J.A.; Testani, D.; Mansur, R.B.; Lee, Y.; Subramaniapillai, M.; McIntyre, R.S. Brain insulin resistance: A treatment target for cognitive impairment and anhedonia in depression. Exp. Neurol. 2019, 315, 1-8. [CrossRef]

59. Chapman, C.D.; Frey, W.H., 2nd; Craft, S.; Danielyan, L.; Hallschmid, M.; Schioth, H.B.; Benedict, C. Intranasal treatment of central nervous system dysfunction in humans. Pharm. Res. 2013, 30, 2475-2484. [CrossRef]

60. McIntyre, R.S.; Soczynska, J.K.; Woldeyohannes, H.O.; Miranda, A.; Vaccarino, A.; Macqueen, G.; Lewis, G.F.; Kennedy, S.H. A randomized, double-blind, controlled trial evaluating the effect of intranasal insulin on neurocognitive function in euthymic patients with bipolar disorder. Bipolar Disord. 2012, 14, 697-706. [CrossRef]

61. Razavi-Nematollahi, L.; Ismail-Beigi, F. Adverse Effects of Glycemia-Lowering Medications in Type 2 Diabetes. Curr. Diabetes Rep. 2019, 19, 132. [CrossRef] [PubMed]

62. Kuhla, A.; Brichmann, E.; Ruhlmann, C.; Thiele, R.; Meuth, L.; Vollmar, B. Metformin Therapy Aggravates Neurodegenerative Processes in ApoE-/- Mice. J. Alzheimer Dis. 2019, 68, 1415-1427. [CrossRef] [PubMed]

63. Moore, E.M.; Mander, A.G.; Ames, D.; Kotowicz, M.A.; Carne, R.P.; Brodaty, H.; Woodward, M.; Boundy, K.; Ellis, K.A.; Bush, A.I.; et al. Increased risk of cognitive impairment in patients with diabetes is associated with metformin. Diabetes Care 2013, 36, 2981-2987. [CrossRef] [PubMed]

64. Weinstein, G.; Davis-Plourde, K.L.; Conner, S.; Himali, J.J.; Beiser, A.S.; Lee, A.; Rawlings, A.M.; Sedaghat, S.; Ding, J.; Moshier, E.; et al. Association of metformin, sulfonylurea and insulin use with brain structure and function and risk of dementia and Alzheimer's disease: Pooled analysis from 5 cohorts. PLoS ONE 2019, 14, e0212293. [CrossRef]

65. Yaribeygi, H.; Ashrafizadeh, M.; Henney, N.C.; Sathyapalan, T.; Jamialahmadi, T.; Sahebkar, A. Neuromodulatory effects of anti-diabetes medications: A mechanistic review. Pharmacol. Res. 2020, 152, 104611. [CrossRef]

66. Sagir, D.; Eren, B.; Yilmaz, B.D.; Eren, Z.; Keles, O.N.; Gokce, A.B. Effects of prenatal PPAR-gamma agonist rosiglitazone exposure on rat hippocampus development in a time-dependent manner: A stereological and histopathological study. Hum. Exp. Toxicol. 2018, 37, 827-835. [CrossRef]

67. Seaquist, E.R.; Miller, M.E.; Fonseca, V.; Ismail-Beigi, F.; Launer, L.J.; Punthakee, Z.; Sood, A. Effect of thiazolidinediones and insulin on cognitive outcomes in ACCORD-MIND. J. Diabetes Complicat. 2013, 27, 485-491. [CrossRef]

68. Zhang, P.; Liu, Y.; Ren, Y.; Bai, J.; Zhang, G.; Cui, Y. The efficacy and safety of liraglutide in the obese, non-diabetic individuals: A systematic review and meta-analysis. Afr. Health Sci. 2019, 19, 2591-2599. [CrossRef]

69. O'Neil, P.M.; Aroda, V.R.; Astrup, A.; Kushner, R.; Lau, D.C.W.; Wadden, T.A.; Brett, J.; Cancino, A.P.; Wilding, J.P.H.; Satiety and Clinical Adiposity-Liraglutide Evidence in Individuals with and without Diabetes (SCALE) Study Groups. Neuropsychiatric safety with liraglutide $3.0 \mathrm{mg}$ for weight management: Results from randomized controlled phase 2 and 3a trials. Diabetes Obes. Metab. 2017, 19, 1529-1536. [CrossRef]

70. Cameron, I.M.; Reid, I.C.; MacGillivray, S.A. Efficacy and tolerability of antidepressants for sub-threshold depression and for mild major depressive disorder. J. Affect. Disord. 2014, 166, 48-58. [CrossRef]

71. Hegerl, U.; Schonknecht, P.; Mergl, R. Are antidepressants useful in the treatment of minor depression: A critical update of the current literature. Curr. Opin. Psychiatry 2012, 25, 1-6. [CrossRef]

72. Roy, T.; Lloyd, C.E. Epidemiology of depression and diabetes: A systematic review. J. Affect. Disord. 2012, 142, S8-S21. [CrossRef]

73. Lloyd, C.E.; Roy, T.; Nouwen, A.; Chauhan, A.M. Epidemiology of depression in diabetes: International and cross-cultural issues. J. Affect. Disord. 2012, 142, S22-S29. [CrossRef]

74. Copps, K.D.; White, M.F. Regulation of insulin sensitivity by serine/threonine phosphorylation of insulin receptor substrate proteins IRS1 and IRS2. Diabetologia 2012, 55, 2565-2582. [CrossRef] [PubMed]

75. Yaribeygi, H.; Farrokhi, F.R.; Butler, A.E.; Sahebkar, A. Insulin resistance: Review of the underlying molecular mechanisms. J. Cell Physiol. 2019, 234, 8152-8161. [CrossRef]

76. Pomytkin, I.; Costa-Nunes, J.P.; Kasatkin, V.; Veniaminova, E.; Demchenko, A.; Lyundup, A.; Lesch, K.P.; Ponomarev, E.D.; Strekalova, T. Insulin receptor in the brain: Mechanisms of activation and the role in the CNS pathology and treatment. CNS Neurosci. Ther. 2018, 24, 763-774. [CrossRef] [PubMed]

77. Bracko, O.; Singer, T.; Aigner, S.; Knobloch, M.; Winner, B.; Ray, J.; Clemenson, G.D., Jr.; Suh, H.; Couillard-Despres, S.; Aigner, L.; et al. Gene expression profiling of neural stem cells and their neuronal progeny reveals IGF2 as a regulator of adult hippocampal neurogenesis. J. Neurosci. 2012, 32, 3376-3387. [CrossRef] 
78. Cline, B.H.; Steinbusch, H.W.; Malin, D.; Revishchin, A.V.; Pavlova, G.V.; Cespuglio, R.; Strekalova, T. The neuronal insulin sensitizer dicholine succinate reduces stress-induced depressive traits and memory deficit: Possible role of insulin-like growth factor 2. BMC Neurosci. 2012, 13, 110. [CrossRef]

79. Pandini, G.; Medico, E.; Conte, E.; Sciacca, L.; Vigneri, R.; Belfiore, A. Differential gene expression induced by insulin and insulin-like growth factor-II through the insulin receptor isoform A. J. Biol. Chem. 2003, 278, 42178-42189. [CrossRef]

80. Bruning, J.C.; Gautam, D.; Burks, D.J.; Gillette, J.; Schubert, M.; Orban, P.C.; Klein, R.; Krone, W.; Muller-Wieland, D.; Kahn, C.R. Role of brain insulin receptor in control of body weight and reproduction. Science 2000, 289, 2122-2125. [CrossRef]

81. Pomytkin, I.; Krasil'nikova, I.; Bakaeva, Z.; Surin, A.; Pinelis, V. Excitotoxic glutamate causes neuronal insulin resistance by inhibiting insulin receptor/Akt/mTOR pathway. Mol. Brain 2019, 12, 112. [CrossRef] [PubMed]

82. Jones, M.L.; Leonard, J.P. PKC site mutations reveal differential modulation by insulin of NMDA receptors containing NR2A or NR2B subunits. J. Neurochem. 2005, 92, 1431-1438. [CrossRef] [PubMed]

83. Christie, J.M.; Wenthold, R.J.; Monaghan, D.T. Insulin causes a transient tyrosine phosphorylation of NR2A and NR2B NMDA receptor subunits in rat hippocampus. J. Neurochem. 1999, 72, 1523-1528. [CrossRef] [PubMed]

84. Skeberdis, V.A.; Lan, J.; Zheng, X.; Zukin, R.S.; Bennett, M.V. Insulin promotes rapid delivery of N-methyl-Daspartate receptors to the cell surface by exocytosis. Proc. Natl. Acad. Sci. USA 2001, 98, 3561-3566. [CrossRef] [PubMed]

85. Krasil'nikova, I.; Surin, A.; Sorokina, E.; Fisenko, A.; Boyarkin, D.; Balyasin, M.; Demchenko, A.; Pomytkin, I.; Pinelis, V. Insulin Protects Cortical Neurons Against Glutamate Excitotoxicity. Front. Neurosci. 2019, 13, 1027. [CrossRef]

86. Schafer, M.; Erdo, S.L. Development of glutamate neurotoxicity in cortical cultures: Induction of vulnerability by insulin. Dev. Brain Res. 1991, 62, 293-296. [CrossRef]

87. Schafer, M.; Erdo, S.L. Insulin-specific sensitization of cultured cerebrocortical neurons to glutamate excitotoxicity. Brain Res. 1992, 580, 331-333. [CrossRef]

88. Nampoothiri, M.; Reddy, N.D.; John, J.; Kumar, N.; Kutty Nampurath, G.; Rao Chamallamudi, M. Insulin blocks glutamate-induced neurotoxicity in differentiated SH-SY5Y neuronal cells. Behav. Neurol. 2014, 2014, 674164. [CrossRef]

89. Datusalia, A.K.; Agarwal, P.; Singh, J.N.; Sharma, S.S. Hyper-insulinemia increases the glutamate-excitotoxicity in cortical neurons: A mechanistic study. Eur. J. Pharmacol. 2018, 833, 524-530. [CrossRef]

90. Abramov, A.Y.; Duchen, M.R. Mechanisms underlying the loss of mitochondrial membrane potential in glutamate excitotoxicity. Biochim. Biophys. Acta 2008, 1777, 953-964. [CrossRef]

91. Zemdegs, J.; Martin, H.; Pintana, H.; Bullich, S.; Manta, S.; Marques, M.A.; Moro, C.; Laye, S.; Ducrocq, F.; Chattipakorn, N.; et al. Metformin Promotes Anxiolytic and Antidepressant-Like Responses in Insulin-Resistant Mice by Decreasing Circulating Branched-Chain Amino Acids. J. Neurosci. 2019, 39, 5935-5948. [CrossRef]

92. Gannon, N.P.; Schnuck, J.K.; Vaughan, R.A. BCAA Metabolism and Insulin Sensitivity-Dysregulated by Metabolic Status? Mol. Nutr. Food Res. 2018, 62, e1700756. [CrossRef] [PubMed]

93. Fernstrom, J.D. Branched-chain amino acids and brain function. J. Nutr. 2005, 135, 1539S-1546S. [CrossRef] [PubMed]

94. Fellendorf, F.T.; Platzer, M.; Pilz, R.; Rieger, A.; Kapfhammer, H.P.; Mangge, H.; Dalkner, N.; Zelzer, S.; Meinitzer, A.; Birner, A.; et al. Branched-chain amino acids are associated with metabolic parameters in bipolar disorder. World J. Biol. Psychiatry 2019, 20, 821-826. [CrossRef] [PubMed]

95. Bansal, Y.; Kuhad, A. Mitochondrial Dysfunction in Depression. Curr. Neuropharmacol. 2016, 14, 610-618. [CrossRef]

96. Allen, J.; Romay-Tallon, R.; Brymer, K.J.; Caruncho, H.J.; Kalynchuk, L.E. Mitochondria and Mood: Mitochondrial Dysfunction as a Key Player in the Manifestation of Depression. Front. Neurosci. 2018, 12, 386. [CrossRef] [PubMed]

97. Sharma, S.; Akundi, R.S. Mitochondria: A Connecting Link in the Major Depressive Disorder Jigsaw. Curr. Neuropharmacol. 2019, 17, 550-562. [CrossRef]

98. Liu, T.; Zhong, S.; Liao, X.; Chen, J.; He, T.; Lai, S.; Jia, Y. A Meta-Analysis of Oxidative Stress Markers in Depression. PLoS ONE 2015, 10, e0138904. [CrossRef]

99. Black, C.N.; Bot, M.; Scheffer, P.G.; Cuijpers, P.; Penninx, B.W. Is depression associated with increased oxidative stress? A systematic review and meta-analysis. Psychoneuroendocrinology 2015, 51, 164-175. [CrossRef] 
100. Czarny, P.; Wigner, P.; Galecki, P.; Sliwinski, T. The interplay between inflammation, oxidative stress, DNA damage, DNA repair and mitochondrial dysfunction in depression. Prog. Neuropsychopharmacol. Biol. Psychiatry 2018, 80, 309-321. [CrossRef]

101. Lu, X.Y. The leptin hypothesis of depression: A potential link between mood disorders and obesity? Curr. Opin. Pharmacol. 2007, 7, 648-652. [CrossRef] [PubMed]

102. Ge, T.; Fan, J.; Yang, W.; Cui, R.; Li, B. Leptin in depression: A potential therapeutic target. Cell Death Dis. 2018, 9, 1096. [CrossRef] [PubMed]

103. Sperlagh, B.; Csolle, C.; Ando, R.D.; Goloncser, F.; Kittel, A.; Baranyi, M. The role of purinergic signaling in depressive disorders. Neuropsychopharmacol. Hung. 2012, 14, 231-238.

104. Pitsillou, E.; Bresnehan, S.M.; Kagarakis, E.A.; Wijoyo, S.J.; Liang, J.; Hung, A.; Karagiannis, T.C. The cellular and molecular basis of major depressive disorder: Towards a unified model for understanding clinical depression. Mol. Biol. Rep. 2020, 47, 753-770. [CrossRef] [PubMed]

105. Leonard, B.; Maes, M. Mechanistic explanations how cell-mediated immune activation, inflammation and oxidative and nitrosative stress pathways and their sequels and concomitants play a role in the pathophysiology of unipolar depression. Neurosci. Biobehav. Rev. 2012, 36, 764-785. [CrossRef] [PubMed]

106. Maes, M.; Ruckoanich, P.; Chang, Y.S.; Mahanonda, N.; Berk, M. Multiple aberrations in shared inflammatory and oxidative \& nitrosative stress (IO\&NS) pathways explain the co-association of depression and cardiovascular disorder (CVD), and the increased risk for CVD and due mortality in depressed patients. Prog. Neuropsychopharmacol. Biol. Psychiatry 2011, 35, 769-783. [CrossRef]

107. Morris, G.; Puri, B.K.; Walker, A.J.; Maes, M.; Carvalho, A.F.; Bortolasci, C.C.; Walder, K.; Berk, M. Shared pathways for neuroprogression and somatoprogression in neuropsychiatric disorders. Neurosci. Biobehav. Rev. 2019, 107, 862-882. [CrossRef]

108. Fang, X.; Zhan, G.; Zhang, J.; Xu, H.; Zhu, B.; Hu, Y.; Yang, C.; Luo, A. Abnormalities in Inflammatory Cytokines Confer Susceptible to Chronic Neuropathic Pain-related Anhedonia in a Rat Model of Spared Nerve Injury. Clin. Psychopharmacol. Neurosci. 2019, 17, 189-199. [CrossRef]

109. De Melo, L.G.P.; Nunes, S.O.V.; Anderson, G.; Vargas, H.O.; Barbosa, D.S.; Galecki, P.; Carvalho, A.F.; Maes, M. Shared metabolic and immune-inflammatory, oxidative and nitrosative stress pathways in the metabolic syndrome and mood disorders. Prog. Neuropsychopharmacol. Biol. Psychiatry 2017, 78, 34-50. [CrossRef]

110. Calle, M.C.; Fernandez, M.L. Inflammation and type 2 diabetes. Diabetes Metab. 2012, 38, 183-191. [CrossRef]

111. Bras, J.P.; Pinto, S.; Almeida, M.I.; Prata, J.; von Doellinger, O.; Coelho, R.; Barbosa, M.A.; Santos, S.G. Peripheral Biomarkers of Inflammation in Depression: Evidence from Animal Models and Clinical Studies. Methods Mol. Biol. 2019, 2011, 467-492. [CrossRef]

112. Moulton, C.D.; Pickup, J.C.; Ismail, K. The link between depression and diabetes: The search for shared mechanisms. Lancet Diabetes Endocrinol. 2015, 3, 461-471. [CrossRef]

113. Kaster, M.P.; Gadotti, V.M.; Calixto, J.B.; Santos, A.R.; Rodrigues, A.L. Depressive-like behavior induced by tumor necrosis factor-alpha in mice. Neuropharmacology 2012, 62, 419-426. [CrossRef] [PubMed]

114. Popov, A.; Abdullah, Z.; Wickenhauser, C.; Saric, T.; Driesen, J.; Hanisch, F.G.; Domann, E.; Raven, E.L.; Dehus, O.; Hermann, C.; et al. Indoleamine 2,3-dioxygenase-expressing dendritic cells form suppurative granulomas following Listeria monocytogenes infection. J. Clin. Investig. 2006, 116, 3160-3170. [CrossRef] [PubMed]

115. Zhu, C.B.; Blakely, R.D.; Hewlett, W.A. The proinflammatory cytokines interleukin-1beta and tumor necrosis factor-alpha activate serotonin transporters. Neuropsychopharmacology 2006, 31, 2121-2131. [CrossRef]

116. Aguirre, V.; Werner, E.D.; Giraud, J.; Lee, Y.H.; Shoelson, S.E.; White, M.F. Phosphorylation of Ser307 in insulin receptor substrate-1 blocks interactions with the insulin receptor and inhibits insulin action. J. Biol. Chem. 2002, 277, 1531-1537. [CrossRef]

117. Peraldi, P.; Spiegelman, B. TNF-alpha and insulin resistance: Summary and future prospects. Mol. Cell. Biochem. 1998, 182, 169-175. [CrossRef]

118. Cheng, Y.; Desse, S.; Martinez, A.; Worthen, R.J.; Jope, R.S.; Beurel, E. TNFalpha disrupts blood brain barrier integrity to maintain prolonged depressive-like behavior in mice. Brain Behav. Immun. 2018, 69, 556-567. [CrossRef]

119. Starr, J.M.; Wardlaw, J.; Ferguson, K.; MacLullich, A.; Deary, I.J.; Marshall, I. Increased blood-brain barrier permeability in type II diabetes demonstrated by gadolinium magnetic resonance imaging. J. Neurol. Neurosurg. Psychiatry 2003, 74, 70-76. [CrossRef] 
120. Varatharaj, A.; Galea, I. The blood-brain barrier in systemic inflammation. Brain Behav. Immun. 2017, 60, 1-12. [CrossRef]

121. Khanzode, S.D.; Dakhale, G.N.; Khanzode, S.S.; Saoji, A.; Palasodkar, R. Oxidative damage and major depression: The potential antioxidant action of selective serotonin re-uptake inhibitors. Redox Rep. Commun. Free Radic. Res. 2003, 8, 365-370. [CrossRef] [PubMed]

122. Herken, H.; Gurel, A.; Selek, S.; Armutcu, F.; Ozen, M.E.; Bulut, M.; Kap, O.; Yumru, M.; Savas, H.A.; Akyol, O. Adenosine deaminase, nitric oxide, superoxide dismutase, and xanthine oxidase in patients with major depression: Impact of antidepressant treatment. Arch. Med. Res. 2007, 38, 247-252. [CrossRef] [PubMed]

123. Ayala, A.; Munoz, M.F.; Arguelles, S. Lipid peroxidation: Production, metabolism, and signaling mechanisms of malondialdehyde and 4-hydroxy-2-nonenal. Oxid. Med. Cell Longev. 2014, 2014, 360438. [CrossRef] [PubMed]

124. Bhatt, S.; Nagappa, A.N.; Patil, C.R. Role of oxidative stress in depression. Drug Discov. Today 2020, 18, 5890-5899. [CrossRef] [PubMed]

125. Moreira, E.G.; Correia, D.G.; Bonifacio, K.L.; Moraes, J.B.; Cavicchioli, F.L.; Nunes, C.S.; Nunes, S.O.V.; Vargas, H.O.; Barbosa, D.S.; Maes, M. Lowered PON1 activities are strongly associated with depression and bipolar disorder, recurrence of (hypo)mania and depression, increased disability and lowered quality of life. World J. Biol. Psychiatry 2019, 20, 368-380. [CrossRef]

126. Lindqvist, D.; Dhabhar, F.S.; James, S.J.; Hough, C.M.; Jain, F.A.; Bersani, F.S.; Reus, V.I.; Verhoeven, J.E.; Epel, E.S.; Mahan, L.; et al. Oxidative stress, inflammation and treatment response in major depression. Psychoneuroendocrinology 2017, 76, 197-205. [CrossRef]

127. Salim, S. Oxidative Stress and the Central Nervous System. J. Pharmacol. Exp. Ther. 2017, 360, 201-205. [CrossRef]

128. Joshi, Y.B.; Pratico, D. Lipid peroxidation in psychiatric illness: Overview of clinical evidence. Oxid. Med. Cell Longev. 2014, 2014, 828702. [CrossRef]

129. Morris, G.; Berk, M.; Galecki, P.; Walder, K.; Maes, M. The Neuro-Immune Pathophysiology of Central and Peripheral Fatigue in Systemic Immune-Inflammatory and Neuro-Immune Diseases. Mol. Neurobiol. 2016, 53, 1195-1219. [CrossRef]

130. Ghasemi, M. Nitric oxide: Antidepressant mechanisms and inflammation. Adv. Pharmacol. 2019, 86, 121-152. [CrossRef]

131. Talarowska, M.; Galecki, P.; Maes, M.; Orzechowska, A.; Chamielec, M.; Bartosz, G.; Kowalczyk, E. Nitric oxide plasma concentration associated with cognitive impairment in patients with recurrent depressive disorder. Neurosci. Lett. 2012, 510, 127-131. [CrossRef]

132. Papageorgiou, C.; Grapsa, E.; Christodoulou, N.G.; Zerefos, N.; Stamatelopoulos, S.; Christodoulou, G.N. Association of serum nitric oxide levels with depressive symptoms: A study with end-stage renal failure patients. Psychother. Psychosom. 2001, 70, 216-220. [CrossRef] [PubMed]

133. Galecki, P.; Szemraj, J.; Bienkiewicz, M.; Florkowski, A.; Galecka, E. Lipid peroxidation and antioxidant protection in patients during acute depressive episodes and in remission after fluoxetine treatment. Pharmacol. Rep. 2009, 61, 436-447. [CrossRef]

134. Jankovic, A.; Korac, A.; Buzadzic, B.; Stancic, A.; Otasevic, V.; Ferdinandy, P.; Daiber, A.; Korac, B. Targeting the NO/superoxide ratio in adipose tissue: Relevance to obesity and diabetes management. Br. J. Pharmacol. 2017, 174, 1570-1590. [CrossRef] [PubMed]

135. Rani, V.; Deep, G.; Singh, R.K.; Palle, K.; Yadav, U.C. Oxidative stress and metabolic disorders: Pathogenesis and therapeutic strategies. Life Sci. 2016, 148, 183-193. [CrossRef]

136. Evans, J.L.; Maddux, B.A.; Goldfine, I.D. The molecular basis for oxidative stress-induced insulin resistance. Antioxid. Redox Signal. 2005, 7, 1040-1052. [CrossRef]

137. Lee, K.U. Oxidative stress markers in Korean subjects with insulin resistance syndrome. Diabetes Res. Clin. Pract. 2001, 54, S29-S33. [CrossRef]

138. Manna, P.; Jain, S.K. Obesity, Oxidative Stress, Adipose Tissue Dysfunction, and the Associated Health Risks: Causes and Therapeutic Strategies. Metab. Syndr. Relat. Disord. 2015, 13, 423-444. [CrossRef]

139. Lu, R.H.; Ji, H.; Chang, Z.G.; Su, S.S.; Yang, G.S. Mitochondrial development and the influence of its dysfunction during rat adipocyte differentiation. Mol. Biol. Rep. 2010, 37, 2173-2182. [CrossRef]

140. Nakazawa, H.; Chang, K.; Shinozaki, S.; Yasukawa, T.; Ishimaru, K.; Yasuhara, S.; Yu, Y.M.; Martyn, J.A.; Tompkins, R.G.; Shimokado, K.; et al. iNOS as a Driver of Inflammation and Apoptosis in Mouse Skeletal Muscle after Burn Injury: Possible Involvement of Sirt1 S-Nitrosylation-Mediated Acetylation of p65 NF-kappaB and p53. PLoS ONE 2017, 12, e0170391. [CrossRef] 
141. Song, Y.S.; Lee, S.K.; Jang, Y.J.; Park, H.S.; Kim, J.H.; Lee, Y.J.; Heo, Y.S. Association between low SIRT1 expression in visceral and subcutaneous adipose tissues and metabolic abnormalities in women with obesity and type 2 diabetes. Diabetes Res. Clin. Pract. 2013, 101, 341-348. [CrossRef] [PubMed]

142. Gillum, M.P.; Kotas, M.E.; Erion, D.M.; Kursawe, R.; Chatterjee, P.; Nead, K.T.; Muise, E.S.; Hsiao, J.J.; Frederick, D.W.; Yonemitsu, S.; et al. SirT1 regulates adipose tissue inflammation. Diabetes 2011, 60, 3235-3245. [CrossRef] [PubMed]

143. Lee, C.C.; Huang, C.C.; Hsu, K.S. Insulin promotes dendritic spine and synapse formation by the PI3K/Akt/mTOR and Rac1 signaling pathways. Neuropharmacology 2011, 61, 867-879. [CrossRef] [PubMed]

144. Van der Heide, L.P.; Kamal, A.; Artola, A.; Gispen, W.H.; Ramakers, G.M. Insulin modulates hippocampal activity-dependent synaptic plasticity in a $\mathrm{N}$-methyl-d-aspartate receptor and phosphatidyl-inositol-3-kinase-dependent manner. J. Neurochem. 2005, 94, 1158-1166. [CrossRef]

145. Adzovic, L.; Domenici, L. Insulin induces phosphorylation of the AMPA receptor subunit GluR1, reversed by ZIP, and over-expression of Protein Kinase M zeta, reversed by amyloid beta. J. Neurochem. 2014, 131, 582-587. [CrossRef]

146. Ge, Y.; Dong, Z.; Bagot, R.C.; Howland, J.G.; Phillips, A.G.; Wong, T.P.; Wang, Y.T. Hippocampal long-term depression is required for the consolidation of spatial memory. Proc. Natl. Acad. Sci. USA 2010, 107, 16697-16702. [CrossRef]

147. Choi, J.; Ko, J.; Racz, B.; Burette, A.; Lee, J.R.; Kim, S.; Na, M.; Lee, H.W.; Kim, K.; Weinberg, R.J.; et al. Regulation of dendritic spine morphogenesis by insulin receptor substrate 53, a downstream effector of Rac1 and Cdc42 small GTPases. J. Neurosci. 2005, 25, 869-879. [CrossRef]

148. Glasper, E.R.; Llorens-Martin, M.V.; Leuner, B.; Gould, E.; Trejo, J.L. Blockade of insulin-like growth factor-I has complex effects on structural plasticity in the hippocampus. Hippocampus 2010, 20, 706-712. [CrossRef]

149. Trejo, J.L.; Piriz, J.; Llorens-Martin, M.V.; Fernandez, A.M.; Bolos, M.; LeRoith, D.; Nunez, A.; Torres-Aleman, I. Central actions of liver-derived insulin-like growth factor I underlying its pro-cognitive effects. Mol. Psychiatry 2007, 12, 1118-1128. [CrossRef]

150. Heni, M.; Hennige, A.M.; Peter, A.; Siegel-Axel, D.; Ordelheide, A.M.; Krebs, N.; Machicao, F.; Fritsche, A.; Haring, H.U.; Staiger, H. Insulin promotes glycogen storage and cell proliferation in primary human astrocytes. PLoS ONE 2011, 6, e21594. [CrossRef]

151. Jesulola, E.; Micalos, P.; Baguley, I.J. Understanding the pathophysiology of depression: From monoamines to the neurogenesis hypothesis model-Are we there yet? Behav. Brain Res. 2018, 341, 79-90. [CrossRef] [PubMed]

152. Fidaleo, M.; Cavallucci, V.; Pani, G. Nutrients, neurogenesis and brain ageing: From disease mechanisms to therapeutic opportunities. Biochem. Pharmacol. 2017, 141, 63-76. [CrossRef] [PubMed]

153. Aberg, M.A.; Aberg, N.D.; Palmer, T.D.; Alborn, A.M.; Carlsson-Skwirut, C.; Bang, P.; Rosengren, L.E.; Olsson, T.; Gage, F.H.; Eriksson, P.S. IGF-I has a direct proliferative effect in adult hippocampal progenitor cells. Mol. Cell. Neurosci. 2003, 24, 23-40. [CrossRef]

154. Sun, L.Y. Hippocampal IGF-1 expression, neurogenesis and slowed aging: Clues to longevity from mutant mice. Age 2006, 28, 181-189. [CrossRef]

155. Brooker, G.J.; Kalloniatis, M.; Russo, V.C.; Murphy, M.; Werther, G.A.; Bartlett, P.F. Endogenous IGF-1 regulates the neuronal differentiation of adult stem cells. J. Neurosci. Res. 2000, 59, 332-341. [CrossRef]

156. Lee, J.; Seroogy, K.B.; Mattson, M.P. Dietary restriction enhances neurotrophin expression and neurogenesis in the hippocampus of adult mice. J. Neurochem. 2002, 80, 539-547. [CrossRef]

157. Fusco, S.; Ripoli, C.; Podda, M.V.; Ranieri, S.C.; Leone, L.; Toietta, G.; McBurney, M.W.; Schutz, G.; Riccio, A.; Grassi, C.; et al. A role for neuronal cAMP responsive-element binding (CREB)-1 in brain responses to calorie restriction. Proc. Natl. Acad. Sci. USA 2012, 109, 621-626. [CrossRef]

158. Renault, V.M.; Rafalski, V.A.; Morgan, A.A.; Salih, D.A.; Brett, J.O.; Webb, A.E.; Villeda, S.A.; Thekkat, P.U.; Guillerey, C.; Denko, N.C.; et al. FoxO 3 regulates neural stem cell homeostasis. Cell Stem Cell 2009, 5, 527-539. [CrossRef]

159. Magri, L.; Cambiaghi, M.; Cominelli, M.; Alfaro-Cervello, C.; Cursi, M.; Pala, M.; Bulfone, A.; Garcia-Verdugo,J.M.; Leocani, L.; Minicucci, F.; et al. Sustained activation of mTOR pathway in embryonic neural stem cells leads to development of tuberous sclerosis complex-associated lesions. Cell Stem Cell 2011, 9, 447-462. [CrossRef]

160. Carroll, B.J.; Cassidy, F.; Naftolowitz, D.; Tatham, N.E.; Wilson, W.H.; Iranmanesh, A.; Liu, P.Y.; Veldhuis, J.D. Pathophysiology of hypercortisolism in depression. Acta Psychiatry Scand. Suppl. 2007, 115, 90-103. [CrossRef] 
161. Oltmanns, K.M.; Dodt, B.; Schultes, B.; Raspe, H.H.; Schweiger, U.; Born, J.; Fehm, H.L.; Peters, A. Cortisol correlates with metabolic disturbances in a population study of type 2 diabetic patients. Eur. J. Endocrinol. 2006, 154, 325-331. [CrossRef] [PubMed]

162. Joseph, J.J.; Golden, S.H. Cortisol dysregulation: The bidirectional link between stress, depression, and type 2 diabetes mellitus. Ann. N. Y. Acad. Sci. 2017, 1391, 20-34. [CrossRef] [PubMed]

163. Yokoyama, K.; Yamada, T.; Mitani, H.; Yamada, S.; Pu, S.; Yamanashi, T.; Matsumura, H.; Nakagome, K.; Kaneko, K. Relationship between hypothalamic-pituitary-adrenal axis dysregulation and insulin resistance in elderly patients with depression. Psychiatry Res. 2015, 226, 494-498. [CrossRef]

164. Diz-Chaves, Y.; Gil-Lozano, M.; Toba, L.; Fandino, J.; Ogando, H.; Gonzalez-Matias, L.C.; Mallo, F. Stressing diabetes? The hidden links between insulinotropic peptides and the HPA axis. J. Endocrinol. 2016, 230, R77-R94. [CrossRef] [PubMed]

165. Gragnoli, C. Hypothesis of the neuroendocrine cortisol pathway gene role in the comorbidity of depression, type 2 diabetes, and metabolic syndrome. Appl. Clin. Genet. 2014, 7, 43-53. [CrossRef]

166. Zou, X.H.; Sun, L.H.; Yang, W.; Li, B.J.; Cui, R.J. Potential role of insulin on the pathogenesis of depression. Cell Prolif. 2020, 53, e12806. [CrossRef]

167. Pariante, C.M.; Miller, A.H. Glucocorticoid receptors in major depression: Relevance to pathophysiology and treatment. Biol. Psychiatry 2001, 49, 391-404. [CrossRef]

168. Pasquali, R.; Vicennati, V.; Cacciari, M.; Pagotto, U. The hypothalamic-pituitary-adrenal axis activity in obesity and the metabolic syndrome. Ann. N. Y. Acad. Sci. 2006, 1083, 111-128. [CrossRef]

169. Van Donkelaar, E.L.; Vaessen, K.R.; Pawluski, J.L.; Sierksma, A.S.; Blokland, A.; Canete, R.; Steinbusch, H.W. Long-term corticosterone exposure decreases insulin sensitivity and induces depressive-like behaviour in the C57BL/6NCrl mouse. PLoS ONE 2014, 9, e106960. [CrossRef]

170. Pan, Y.; Hong, Y.; Zhang, Q.Y.; Kong, L.D. Impaired hypothalamic insulin signaling in CUMS rats: Restored by icariin and fluoxetine through inhibiting CRF system. Psychoneuroendocrinology 2013, 38, 122-134. [CrossRef]

171. Osmanovic, J.; Plaschke, K.; Salkovic-Petrisic, M.; Grunblatt, E.; Riederer, P.; Hoyer, S. Chronic exogenous corticosterone administration generates an insulin-resistant brain state in rats. Stress 2010, 13, 123-131. [CrossRef] [PubMed]

172. Solas, M.; Gerenu, G.; Gil-Bea, F.J.; Ramirez, M.J. Mineralocorticoid receptor activation induces insulin resistance through c-Jun $\mathrm{N}$-terminal kinases in response to chronic corticosterone: Cognitive implications. J. Neuroendocrinol. 2013, 25, 350-356. [CrossRef] [PubMed]

173. Inouye, K.E.; Chan, O.; Yue, J.T.; Andrews, M.; Li, Q.; Matthews, S.G.; Vranic, M. The effect of long-term insulin treatment with and without antecedent hypoglycemia on neuropeptide and corticosteroid receptor expression in the brains of diabetic rats. Brain Res. Bull. 2008, 77, 149-157. [CrossRef] [PubMed]

174. Mahana, D.; Trent, C.M.; Kurtz, Z.D.; Bokulich, N.A.; Battaglia, T.; Chung, J.; Muller, C.L.; Li, H.; Bonneau, R.A.; Blaser, M.J. Antibiotic perturbation of the murine gut microbiome enhances the adiposity, insulin resistance, and liver disease associated with high-fat diet. Genome Med. 2016, 8, 48. [CrossRef]

175. Ait-Belgnaoui, A.; Durand, H.; Cartier, C.; Chaumaz, G.; Eutamene, H.; Ferrier, L.; Houdeau, E.; Fioramonti, J.; Bueno, L.; Theodorou, V. Prevention of gut leakiness by a probiotic treatment leads to attenuated HPA response to an acute psychological stress in rats. Psychoneuroendocrinology 2012, 37, 1885-1895. [CrossRef]

176. Pandey, S.; Singh, A.; Chaudhari, N.; Nampoothiri, L.P.; Kumar, G.N. Protection against 1,2-di-methylhydrazine-induced systemic oxidative stress and altered brain neurotransmitter status by probiotic Escherichia coli CFR 16 secreting pyrroloquinoline quinone. Curr. Microbiol. 2015, 70, 690-697. [CrossRef]

177. Soto, M.; Herzog, C.; Pacheco, J.A.; Fujisaka, S.; Bullock, K.; Clish, C.B.; Kahn, C.R. Gut microbiota modulate neurobehavior through changes in brain insulin sensitivity and metabolism. Mol. Psychiatry 2018, 23, 2287-2301. [CrossRef]

178. Morshedi, M.; Valenlia, K.B.; Hosseinifard, E.S.; Shahabi, P.; Abbasi, M.M.; Ghorbani, M.; Barzegari, A.; Sadigh-Eteghad, S.; Saghafi-Asl, M. Beneficial psychological effects of novel psychobiotics in diabetic rats: The interaction among the gut, blood and amygdala. J. Nutr. Biochem. 2018, 57, 145-152. [CrossRef]

179. Puddu, A.; Sanguineti, R.; Montecucco, F.; Viviani, G.L. Evidence for the gut microbiota short-chain fatty acids as key pathophysiological molecules improving diabetes. Mediat. Inflamm. 2014, 2014, 162021. [CrossRef]

180. Kyriachenko, Y.; Falalyeyeva, T.; Korotkyi, O.; Molochek, N.; Kobyliak, N. Crosstalk between gut microbiota and antidiabetic drug action. World J. Diabetes 2019, 10, 154-168. [CrossRef] 
181. Shin, N.R.; Lee, J.C.; Lee, H.Y.; Kim, M.S.; Whon, T.W.; Lee, M.S.; Bae, J.W. An increase in the Akkermansia spp. population induced by metformin treatment improves glucose homeostasis in diet-induced obese mice. Gut 2014, 63, 727-735. [CrossRef] [PubMed]

182. Wang, L.; Li, P.; Tang, Z.; Yan, X.; Feng, B. Structural modulation of the gut microbiota and the relationship with body weight: Compared evaluation of liraglutide and saxagliptin treatment. Sci. Rep. 2016, 6, 33251. [CrossRef] [PubMed]

183. Jain, A.K.; Vaidya, A.; Ravichandran, V.; Kashaw, S.K.; Agrawal, R.K. Recent developments and biological activities of thiazolidinone derivatives: A review. Bioorg. Med. Chem. 2012, 20, 3378-3395. [CrossRef] [PubMed]

184. Bai, J.; Zhu, Y.; Dong, Y. Response of gut microbiota and inflammatory status to bitter melon (Momordica charantia L.) in high fat diet induced obese rats. J. Ethnopharmacol. 2016, 194, 717-726. [CrossRef]

185. Baggio, L.L.; Drucker, D.J. Glucagon-like peptide-1 receptors in the brain: Controlling food intake and body weight. J. Clin. Investig. 2014, 124, 4223-4226. [CrossRef]

186. Sulistio, M.; Carothers, C.; Mangat, M.; Lujan, M.; Oliveros, R.; Chilton, R. GLP-1 agonist-based therapies: An emerging new class of antidiabetic drug with potential cardioprotective effects. Curr. Atheroscler. Rep. 2009, 11, 93-99. [CrossRef]

187. Muscogiuri, G.; DeFronzo, R.A.; Gastaldelli, A.; Holst, J.J. Glucagon-like Peptide-1 and the Central/Peripheral Nervous System: Crosstalk in Diabetes. Trends Endocrinol. Metab. 2017, 28, 88-103. [CrossRef]

188. Kanoski, S.E.; Fortin, S.M.; Arnold, M.; Grill, H.J.; Hayes, M.R. Peripheral and central GLP-1 receptor populations mediate the anorectic effects of peripherally administered GLP-1 receptor agonists, liraglutide and exendin-4. Endocrinology 2011, 152, 3103-3112. [CrossRef]

189. Kastin, A.J.; Akerstrom, V.; Pan, W. Interactions of glucagon-like peptide-1 (GLP-1) with the blood-brain barrier. J. Mol. Neurosci. 2002, 18, 7-14. [CrossRef]

190. Gejl, M.; Brock, B.; Egefjord, L.; Vang, K.; Rungby, J.; Gjedde, A. Blood-Brain Glucose Transfer in Alzheimer's disease: Effect of GLP-1 Analog Treatment. Sci. Rep. 2017, 7, 17490. [CrossRef]

191. Holscher, C. Central effects of GLP-1: New opportunities for treatments of neurodegenerative diseases. J. Endocrinol. 2014, 221, T31-T41. [CrossRef] [PubMed]

192. Abbas, T.; Faivre, E.; Holscher, C. Impairment of synaptic plasticity and memory formation in GLP-1 receptor KO mice: Interaction between type 2 diabetes and Alzheimer's disease. Behav. Brain Res. 2009, 205, $265-271$. [CrossRef] [PubMed]

193. Gengler, S.; McClean, P.L.; McCurtin, R.; Gault, V.A.; Holscher, C. Val(8)GLP-1 rescues synaptic plasticity and reduces dense core plaques in APP/PS1 mice. Neurobiol. Aging 2012, 33, 265-276. [CrossRef] [PubMed]

194. Athauda, D.; Foltynie, T. The glucagon-like peptide 1 (GLP) receptor as a therapeutic target in Parkinson's disease: Mechanisms of action. Drug Discov. Today 2016, 21, 802-818. [CrossRef]

195. Reddy, I.A.; Pino, J.A.; Weikop, P.; Osses, N.; Sorensen, G.; Bering, T.; Valle, C.; Bluett, R.J.; Erreger, K.; Wortwein, G.; et al. Glucagon-like peptide 1 receptor activation regulates cocaine actions and dopamine homeostasis in the lateral septum by decreasing arachidonic acid levels. Transl. Psychiatry 2016, 6, e809. [CrossRef]

196. Fortin, S.M.; Roitman, M.F. Central GLP-1 receptor activation modulates cocaine-evoked phasic dopamine signaling in the nucleus accumbens core. Physiol. Behav. 2017, 176, 17-25. [CrossRef]

197. Kleinridders, A.; Pothos, E.N. Impact of Brain Insulin Signaling on Dopamine Function, Food Intake, Reward, and Emotional Behavior. Curr. Nutr. Rep. 2019, 8, 83-91. [CrossRef]

198. Grieco, M.; Giorgi, A.; Gentile, M.C.; d’Erme, M.; Morano, S.; Maras, B.; Filardi, T. Glucagon-Like Peptide-1: A Focus on Neurodegenerative Diseases. Front. Neurosci. 2019, 13, 1112. [CrossRef]

199. Hamilton, A.; Patterson, S.; Porter, D.; Gault, V.A.; Holscher, C. Novel GLP-1 mimetics developed to treat type 2 diabetes promote progenitor cell proliferation in the brain. J. Neurosci. Res. 2011, 89, 481-489. [CrossRef]

200. Salagre, E.; Sole, B.; Tomioka, Y.; Fernandes, B.S.; Hidalgo-Mazzei, D.; Garriga, M.; Jimenez, E.; Sanchez-Moreno, J.; Vieta, E.; Grande, I. Treatment of neurocognitive symptoms in unipolar depression: A systematic review and future perspectives. J. Affect. Disord. 2017, 221, 205-221. [CrossRef]

201. Baune, B.T.; Renger, L. Pharmacological and non-pharmacological interventions to improve cognitive dysfunction and functional ability in clinical depression-A systematic review. Psychiatry Res. 2014, 219, $25-50$. [CrossRef] [PubMed]

202. Mansur, R.B.; Brietzke, E.; McIntyre, R.S. Is there a "metabolic-mood syndrome"? A review of the relationship between obesity and mood disorders. Neurosci. Biobehav. Rev. 2015, 52, 89-104. [CrossRef] [PubMed] 
203. Rena, G.; Hardie, D.G.; Pearson, E.R. The mechanisms of action of metformin. Diabetologia 2017, 60, 1577-1585. [CrossRef] [PubMed]

204. Wang, Y.; Liu, B.; Yang, Y.; Wang, Y.; Zhao, Z.; Miao, Z.; Zhu, J. Metformin exerts antidepressant effects by regulated DNA hydroxymethylation. Epigenomics 2019, 11, 655-667. [CrossRef]

205. Steinberg, G.R.; Kemp, B.E. AMPK in Health and Disease. Physiol. Rev. 2009, 89, 1025-1078. [CrossRef]

206. Keshavarzi, S.; Kermanshahi, S.; Karami, L.; Motaghinejad, M.; Motevalian, M.; Sadr, S. Protective role of metformin against methamphetamine induced anxiety, depression, cognition impairment and neurodegeneration in rat: The role of CREB/BDNF and Akt/GSK3 signaling pathways. Neurotoxicology 2019, 72, 74-84. [CrossRef]

207. Rotermund, C.; Machetanz, G.; Fitzgerald, J.C. The Therapeutic Potential of Metformin in Neurodegenerative Diseases. Front. Endocrinol. 2018, 9, 400. [CrossRef]

208. Lv, W.S.; Wen, J.P.; Li, L.; Sun, R.X.; Wang, J.; Xian, Y.X.; Cao, C.X.; Wang, Y.L.; Gao, Y.Y. The effect of metformin on food intake and its potential role in hypothalamic regulation in obese diabetic rats. Brain Res. 2012, 1444, 11-19. [CrossRef]

209. Hyun, B.; Shin, S.; Lee, A.; Lee, S.; Song, Y.; Ha, N.J.; Cho, K.H.; Kim, K. Metformin Down-regulates TNF-alpha Secretion via Suppression of Scavenger Receptors in Macrophages. Immune Netw. 2013, 13, 123-132. [CrossRef]

210. Misiak, B.; Beszlej, J.A.; Kotowicz, K.; Szewczuk-Boguslawska, M.; Samochowiec, J.; Kucharska-Mazur, J.; Frydecka, D. Cytokine alterations and cognitive impairment in major depressive disorder: From putative mechanisms to novel treatment targets. Prog. Neuropsychopharmacol. Biol. Psychiatry 2018, 80, 177-188. [CrossRef]

211. Dowlati, Y.; Herrmann, N.; Swardfager, W.; Liu, H.; Sham, L.; Reim, E.K.; Lanctot, K.L. A meta-analysis of cytokines in major depression. Biol. Psychiatry 2010, 67, 446-457. [CrossRef] [PubMed]

212. Ying, M.A.; Maruschak, N.; Mansur, R.; Carvalho, A.F.; Cha, D.S.; McIntyre, R.S. Metformin: Repurposing opportunities for cognitive and mood dysfunction. CNS Neurol. Disord. Drug Targets 2014, 13, 1836-1845. [CrossRef] [PubMed]

213. Pan, H.; Wang, H.; Zhu, L.; Mao, L.; Qiao, L.; Su, X. Depletion of Nrf2 enhances inflammation induced by oxyhemoglobin in cultured mice astrocytes. Neurochem. Res. 2011, 36, 2434-2441. [CrossRef] [PubMed]

214. Maes, M.; Fisar, Z.; Medina, M.; Scapagnini, G.; Nowak, G.; Berk, M. New drug targets in depression: Inflammatory, cell-mediated immune, oxidative and nitrosative stress, mitochondrial, antioxidant, and neuroprogressive pathways. And new drug candidates-Nrf2 activators and GSK-3 inhibitors. Inflammopharmacology 2012, 20, 127-150. [CrossRef] [PubMed]

215. Markowicz-Piasecka, M.; Sikora, J.; Szydlowska, A.; Skupien, A.; Mikiciuk-Olasik, E.; Huttunen, K.M. Metformin-A Future Therapy for Neurodegenerative Diseases: Theme: Drug Discovery, Development and Delivery in Alzheimer's Disease Guest Editor: Davide Brambilla. Pharm. Res. 2017, 34, 2614-2627. [CrossRef]

216. Zhao, Z.; Cheng, X.; Wang, Y.; Han, R.; Li, L.; Xiang, T.; He, L.; Long, H.; Zhu, B.; He, Y. Metformin inhibits the IL-6-induced epithelial-mesenchymal transition and lung adenocarcinoma growth and metastasis. PLOS ONE 2014, 9, e95884. [CrossRef]

217. Felger, J.C.; Lotrich, F.E. Inflammatory cytokines in depression: Neurobiological mechanisms and therapeutic implications. Neuroscience 2013, 246, 199-229. [CrossRef]

218. Baumeister, D.; Russell, A.; Pariante, C.M.; Mondelli, V. Inflammatory biomarker profiles of mental disorders and their relation to clinical, social and lifestyle factors. Soc. Psychiatry Psychiatr. Epidemiol. 2014, 49, 841-849. [CrossRef]

219. Vojvodic, J.; Mihajlovic, G.; Vojvodic, P.; Radomirovic, D.; Vojvodic, A.; Vlaskovic-Jovicevic, T.; Peric-Hajzler, Z.; Matovic, D.; Dimitrijevic, S.; Sijan, G.; et al. The Impact of Immunological Factors on Depression Treatment-Relation between Antidepressants and Immunomodulation Agents. Open Access Maced. J. Med Sci. 2019, 7, 3064-3069. [CrossRef]

220. Tan, C.K.; Zhuang, Y.; Wahli, W. Synthetic and natural Peroxisome Proliferator-Activated Receptor (PPAR) agonists as candidates for the therapy of the metabolic syndrome. Expert Opin. Ther. Targets 2017, 21, 333-348. [CrossRef]

221. Berger, J.; Moller, D.E. The mechanisms of action of PPARs. Annu. Rev. Med. 2002, 53, 409-435. [CrossRef] [PubMed]

222. Towfighi, A.; Ovbiagele, B. Partial peroxisome proliferator-activated receptor agonist angiotensin receptor blockers. Potential multipronged strategy in stroke prevention. Cerebrovasc. Dis. 2008, 26, 106-112. [CrossRef] [PubMed] 
223. Combs, C.K.; Johnson, D.E.; Karlo, J.C.; Cannady, S.B.; Landreth, G.E. Inflammatory mechanisms in Alzheimer's disease: Inhibition of beta-amyloid-stimulated proinflammatory responses and neurotoxicity by PPARgamma agonists. J. Neurosci. 2000, 20, 558-567. [CrossRef] [PubMed]

224. Kintscher, U.; Law, R.E. PPARgamma-mediated insulin sensitization: The importance of fat versus muscle. Am. J. Physiol. Endocrinol. Metab. 2005, 288, 287-291. [CrossRef] [PubMed]

225. Pipatpiboon, N.; Pratchayasakul, W.; Chattipakorn, N.; Chattipakorn, S.C. PPARgamma agonist improves neuronal insulin receptor function in hippocampus and brain mitochondria function in rats with insulin resistance induced by long term high-fat diets. Endocrinology 2012, 153, 329-338. [CrossRef] [PubMed]

226. Sharma, A.N.; Elased, K.M.; Lucot, J.B. Rosiglitazone treatment reversed depression- but not psychosis-like behavior of $\mathrm{db} / \mathrm{db}$ diabetic mice. J. Psychopharmacol. 2012, 26, 724-732. [CrossRef]

227. Chua, S.C., Jr.; Chung, W.K.; Wu-Peng, X.S.; Zhang, Y.; Liu, S.M.; Tartaglia, L.; Leibel, R.L. Phenotypes of mouse diabetes and rat fatty due to mutations in the OB (leptin) receptor. Science 1996, 271, 994-996. [CrossRef]

228. Sharma, P.K.; Dutta, R.K.; Pandey, A.C. Alteration of magnetic and optical properties of ultrafine dilute magnetic semiconductor $\mathrm{ZnO}: \mathrm{Co}^{2+}$ nanoparticles. J. Colloid Interface Sci. 2010, 345, 149-153. [CrossRef]

229. Skerrett, R.; Pellegrino, M.P.; Casali, B.T.; Taraboanta, L.; Landreth, G.E. Combined Liver X Receptor/Peroxisome Proliferator-activated Receptor gamma Agonist Treatment Reduces Amyloid beta Levels and Improves Behavior in Amyloid Precursor Protein/Presenilin 1 Mice. J. Biol. Chem. 2015, 290, 21591-21602. [CrossRef]

230. Carta, A.R. PPAR-gamma: Therapeutic prospects in Parkinson's disease. Current Drug Targets 2013, 14, 743-751. [CrossRef]

231. Lecca, D.; Nevin, D.K.; Mulas, G.; Casu, M.A.; Diana, A.; Rossi, D.; Sacchetti, G.; Fayne, D.; Carta, A.R. Neuroprotective and anti-inflammatory properties of a novel non-thiazolidinedione PPARgamma agonist in vitro and in MPTP-treated mice. Neuroscience 2015, 302, 23-35. [CrossRef] [PubMed]

232. Hegazy, M.; El-Shafey, M.; Abulsoud, A.I.; Elsadek, B.E.M.; Abd Elaziz, A.I.; Salama, S.A. Pioglitazone ameliorates high fat diet-induced hypertension and induces catechol o-methyl transferase expression in rats. Eur. J. Pharmacol. 2020, 885, 173383. [CrossRef] [PubMed]

(C) 2020 by the authors. Licensee MDPI, Basel, Switzerland. This article is an open access article distributed under the terms and conditions of the Creative Commons Attribution (CC BY) license (http://creativecommons.org/licenses/by/4.0/). 